Surface-Water Quality Data, Permanente and Saratoga Creeks, Santa Clara Valley, California, Water Year 1997

By Seth H. Myhre and Kenneth E. Bencala

U.S. GEOLOGICAL SURVEY

Open-File Report 98-4

Menlo Park, California 1998 


\section{U.S. DEPARTMENT OF INTERIOR}

\section{BRUCE BABBITT, Secretary}

\section{U.S. GEOLOGICAL SURVEY}

Mark Shaefer, Acting Director

For additional information write to:

U.S. Geological Survey, WRD 345 Middlefield Road

Menlo Park, California 94025
Copies of this report can be purchased from :

\author{
U.S. Geological Survey \\ Branch of Information Services \\ Box 25286 \\ Denver Federal Center \\ Denver, Colorado 80225-0046
}




\section{CONTENTS}

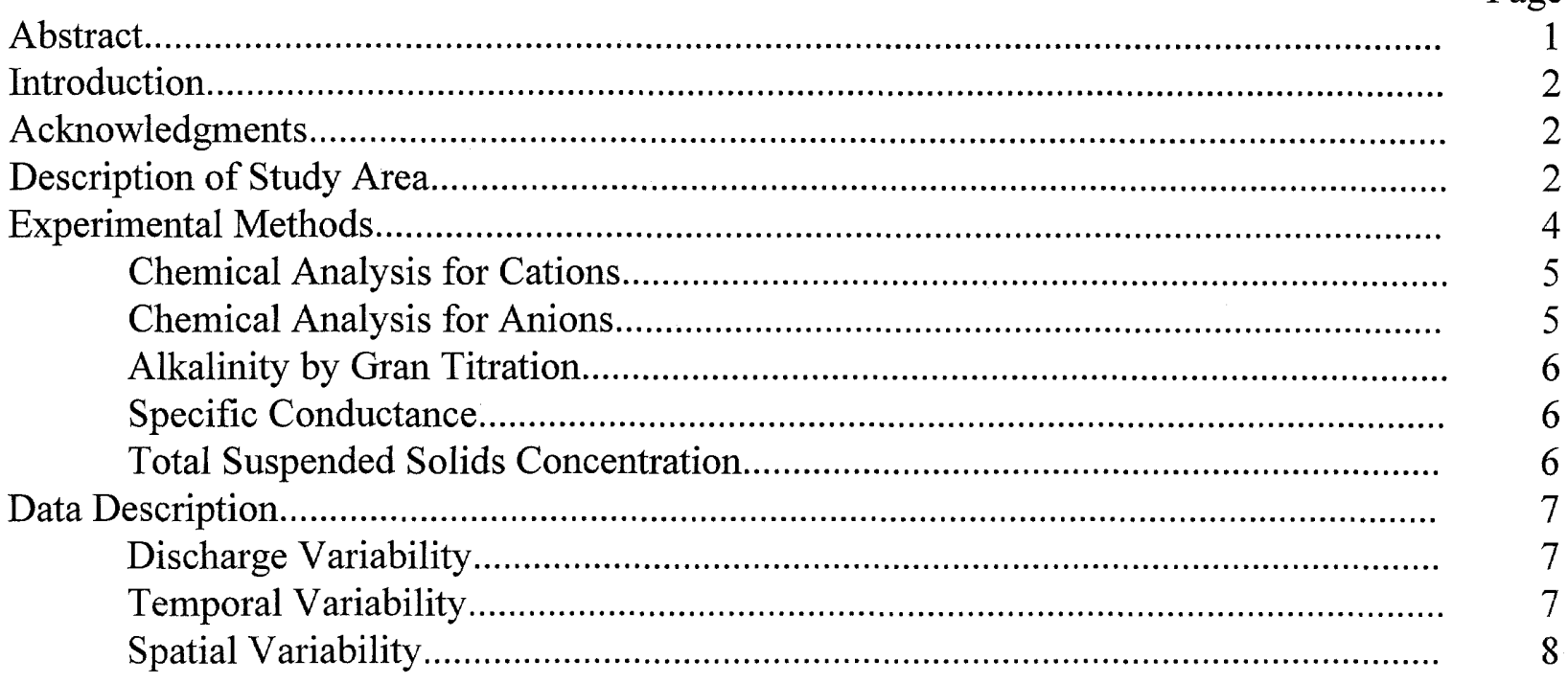

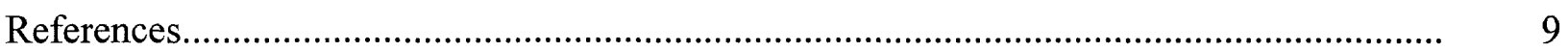

\section{FIGURES}

1. Location of study area............................................................................ 10

2. Permanente and Saratoga Creek hydrograph for water Year 1997............... 12

3-11. Plots showing temporal variability:

3. Temporal variability of $\mathrm{pH}$ at $\mathrm{PR} 1$ and SA3, hydrograph of Permanente and Saratoga Creeks.................................................................................... 13

4. Temporal variability of temperature at PR1 and SA3, hydrograph of Permanente and Saratoga Creeks................................................................................. 14

5. Temporal variability of chloride concentration at PR1 and SA3, hydrograph of Permanente and Saratoga Creeks............................................................... 15

6. Temporal variability of specific conductance at PR1 and SA3, hydrograph of Permanente and Saratoga Creeks............................................................... 16

7. Temporal variability of alkalinity at PR1 and SA3, hydrograph of Permanente and Saratoga Creeks.............................................................................. 17

8. Temporal variability of sulfate concentration at PR1 and SA3, hydrograph of Permanente and Saratoga Creeks. 
9. Temporal variability of calcium concentration at PR1 and SA3, hydrograph of Permanente and Saratoga Creeks................................................................. 19

10. Temporal variability of magnesium concentration at PR1 and SA3, hydrograph of Permanente and Saratoga Creeks............................................................ $\quad 20$

11. Temporal variability of sodium concentration at PR1 and SA3, hydrograph of Permanente and Saratoga Creeks

12-20. Plots showing spatial variability:

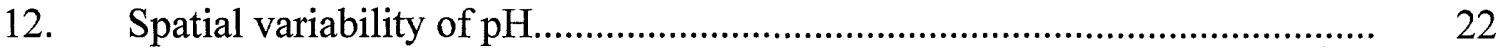

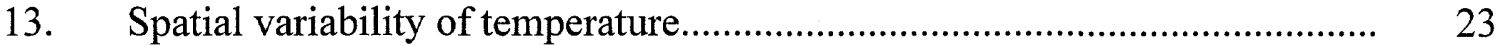

14. Spatial variability of chloride concentration............................................. 24

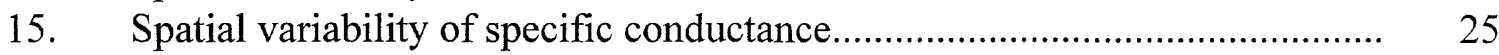

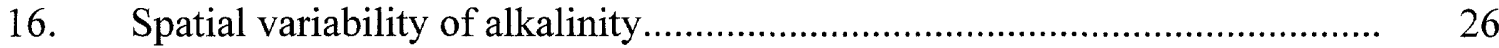

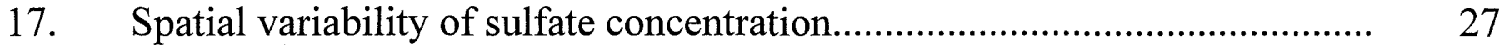

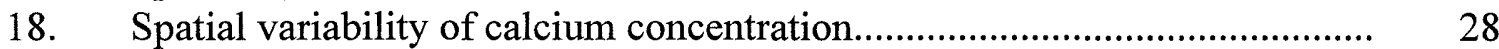

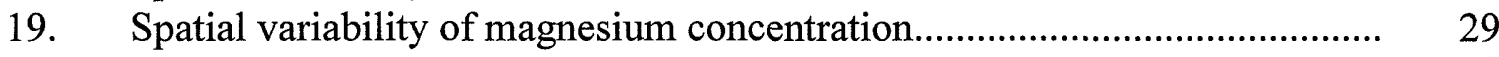

20. Spatial variability of sodium concentration......................................... 30

\section{TABLES}

1. Permanente and Saratoga Creeks discharge on sampling date

2-18. Measurements from Permanente and Saratoga Creek (data tables):

2. October 1,1996 .

3. October 24, 1996.

4. November 5, 1996

5. Novemver 20, 1996

6. December 3, 1996

7. December 12, 1996 .

8. January 2, 1997

9. January 13,1997

10. January 27,1997

11. February 5, 1997

12. March 3, 1997

13. April 1, 1997

14. May 2, 1997

15. June 10, 1997

16. July 8, 1997 .

17. August 15, 1997.

18. September 18, 1997. 
CONVERSION FACTORS

\begin{tabular}{lll}
\hline Multiply & By & To Obtain \\
\hline & & \\
cubic foot per second $\left(\mathrm{ft}^{3} / \mathrm{s}\right)$ & 0.02832 & cubic meter per second $\left(\mathrm{m}^{3} / \mathrm{s}\right)$ \\
gallon (gal) & 0.003785 & cubic meter $\left(\mathrm{m}^{3}\right)$ \\
mile (mi) & 1.609 & kilometer $(\mathrm{km})$ \\
square mile $\left(\mathrm{mi}^{2}\right)$ & 2.59 & square kilometer $\left(\mathrm{km}^{2}\right)$ \\
gram (g) & 0.035 & ounce $(\mathrm{oz})$ \\
inch (in) & 2.54 & centimeter $(\mathrm{cm})$ \\
\hline
\end{tabular}

Degrees Celsius $\left({ }^{\circ} \mathrm{C}\right)$ may be converted to degrees Fahrenheit $\left({ }^{\circ} \mathrm{F}\right)$ by using the following equation:

${ }^{\circ} \mathrm{F}=9 / 5\left({ }^{\circ} \mathrm{C}\right)+32$

Any use of trade, product, or firm names is for descriptive purposes only and does not constitute endorsement by the U.S. government. 


\title{
Surface-Water Quality Data, Permanente and Saratoga Creeks, Santa Clara Valley, California, Water Year 1997
}

By Seth H. Myhre and Kenneth E. Bencala

\begin{abstract}
The U.S. Geological Survey (USGS) monitored selected water quality characteristics at three sites along Permanente Creek and six sites along Saratoga Creek from October 1, 1996 through September 18, 1997. Water samples were collected one to three times per month, depending on rainfall. Samples were measured in the laboratory for alkalinity, specific conductance, total suspended solids, and chloride, sulfate, calcium, magnesium and sodium concentrations. Temperature and $\mathrm{pH}$ were measured directly in the creeks. This report presents tabulated data from these measurements. This report also presents a description of the data and a graphical presentation of the constituents and discharge.
\end{abstract}




\section{INTRODUCTION}

This study was designed to monitor spatial and temporal variability of selected water quality characteristics in Permanente and Saratoga Creeks during the 1997 water year (October 1, 1996 through September 30, 1997). The chemical and physical data presented in this report will be used to determine the applicability of Permanente and Saratoga Creeks for future studies. This report presents physical and chemical data, figures which display spatial and temporal variability of the data, a description of the study area and of the methods used in the field and in the laboratory. This report also presents discharge data for Permanente and Saratoga Creeks, however these data were measured independently of this study.

\section{Acknowledgments}

Many people helped in the prepartaration of this report. Permanente Creek discharge data were provided by Santa Clara Valley Water District (SCVWD) (gaging station number 32A). Saratoga Creek discharge was provided by the California District of the USGS Water Resources Division (gaging station number 11169500). The USGS and SCVWD gaging stations were set up independently, prior to this study, and are currently in operation. Larry Schemel designed and supervised the experiment, provided the necessary training for sample collection and processing, laboratory procedures, computer skills, and writing of the data report. Ron Avanzino provided training on the Dionex Ion Chromatograph and general laboratory protocol.

\section{DESCRIPTION OF STUDY AREA}

Permanente and Saratoga Creeks are located in the northwestern (NW) section of Santa Clara County California (fig. 1). Santa Clara County is located approximately forty miles south of San Francisco on the east side of the Santa Cruz Mountains. Drainage basins for Permanente and Saratoga Creeks are oriented west to east. Permanente and Saratoga Creeks drain to the San Francisco Bay. See figure 1 for site locations.

Permanente Creek water samples were collected at three sites: two along Permanente 
Creek and one along West Fork Permanente Creek. A cement plant and limestone quarrying operation heavily impacted Permanente Creek upstream from the sampling sites (Nolan and Hill, 1989). Permanente Creek was impacted by channelization and suburbanization downstream from the sampling sites. West Fork Permanente Creek was unimpacted upstream from its sampling site.

Permanente Creek sites are identified with a "PR" prefix. Site numbers descend downstream. PR3 was on West Fork Permanente Creek, upstream from the confluence with Permanente Creek. PR2 was on Permanente Creek, upstream from the confluence with West Fork Permanente Creek. PR1 was on Permanente Creek, downstream from the confluence with West Fork Permanente Creek.

Saratoga Creek water samples were collected at six sites: four along Saratoga Creek, one along Mc Elroy Creek (tributary), and one along San Andreas Creek (tributary). Saratoga Creek was impacted by a sparse residential population upstream from the sampling sites, and by suburbanization downstream from the sampling sites. Mc Elroy and San Andreas Creeks were unimpacted upstream from their sampling sites.

Saratoga Creek sites are identified with a "SA" prefix. Suffixes descend downstream. SA6 was on Saratoga Creek downstream from the confluence of Booker Creek. SA5 was on Mc Elroy Creek upstream from the confluence with San Andreas. SA4 was on San Andreas Creek upstream from the confluence with Mc Elroy. SA3 was on Saratoga Creek, downstream from the confluence of Mc Elroy Creek with Saratoga Creek. SA2 was on Saratoga Creek, in the town of Saratoga. SA1 was the furthest downstream site on Saratoga Creek. SA1 was located in the city of San Jose, on the north side of Prospect Avenue. Saratoga Creek enters a cement channel between SA2 and SA1, and remains channelized untill discharging into the San Francisco Bay. 


\section{EXPERIMENTAL METHODS}

One water sample was collected at each site. Collection frequency varied from one to three times per month depending on rainfall. Each water sample was collected in a 1,000 ml Nalgene polyethylene bottle using the single-vertical method (Ward and Harr, 1990). Collection bottles were rinsed in the laboratory with deionized water (DIW), field rinsed with stream water, and marked with their corresponding sites before each use.

Water temperature and $\mathrm{pH}$ were measured directly in the creeks during sample collection with a Cole-Parmer $\mathrm{pH} / \mathrm{mV} /{ }^{\circ} \mathrm{C}$ meter (model 59002-00). The meter was calibrated before each measurement with $\mathrm{pH} 7$ and $\mathrm{pH} 4$ buffers. Buffer solutions were made the evening prior to use. The $\mathrm{pH} 4$ buffer solution was made by dissolving $5.1 \mathrm{~g}$ of Beckman potassium biphthalate in DIW to a solution volume of $500 \mathrm{ml}$. The $\mathrm{pH} 7$ buffer was made by dissolving $3.3 \mathrm{~g}$ of Beckman Phosphate Buffer in DIW to a solution volume of $500 \mathrm{ml}$.

Samples were processed and preserved as described by Ward and Harr (1990). Samples to be measured for selected ion concentrations, alkalinity, and total suspended solids concentrations (TSS) were filtered in the laboratory on collection day through $47 \mathrm{~mm}$ diameter, 0.45 micron pore size Gelman polycarbonate membrane filters. The filters were placed in an acid-washed Sartorious filter holder which was attached to a hand vacuum pump. The filter, filter holder, and storage bottles were rinsed several times with filtrate before receiving a final aliquot. Specific conductance samples were not filtered prior to analysis. All samples were refrigerated after processing.

Water samples were analyzed in the laboratory for major cations: magnesium $\left(\mathrm{Mg}^{2+}\right)$, calcium $\left(\mathrm{Ca}^{2+}\right)$ and sodium $\left(\mathrm{Na}^{+}\right)$, anions: chloride $\left(\mathrm{Cl}^{-}\right)$and sulfate $\left(\mathrm{SO}_{4}{ }^{2-}\right)$, and alkalinity, specific conductance and total suspended solids concentration. The laboratory analyses usually were done several weeks after collection. 


\section{Chemical Analysis for Cations}

The water samples to be analyzed for sodium, magnesium and calcium were preserved immediately after processing by adding $1 \mathrm{ml}$ of concentrated nitric acid $\left(\mathrm{HNO}_{3}\right)$ to approximately $100 \mathrm{ml}$ of sample (Ward and Harr 1990; Shelton, 1994). On the day of analyses lanthanum chloride $\left(\mathrm{LaCl}_{3}\right)$ was added to sample aliquots to be measured for calcium and magnesium. Lanthanum chloride was added to mask possible interferences of phosphate, sulfate, and aluminum (Fishman and Friedman, 1989).

The analyses were executed by direct aspiration of a sample to a Perkin Elmer Atomic Absorption Spectrophotometer model 603. Most samples were left undiluted. Occasionally samples analyzed for sodium and calcium were diluted with a 2 percent hydrochloric acid $(\mathrm{HCl})$ solution. Samples were diluted in order to bring their cation concentrations within the linear dynamic range for the wavelength at which they were measured. Instrumental drift was corrected for by analyzing blanks and standards between sample sets.

\section{Chemical Analysis for Anions}

Analyses were performed on a Dionex DX 500 Ion Chromatograph using the Fishman and Friedman analytical method (1989). All samples were undiluted. Instrumental drift was corrected for by analyzing blanks and standards between sample sets. 


\section{Alkalinity by Gran Titration}

Alkalinity was determined by an $\mathrm{HCl}$ titration, as outlined by Gran (1952). The titration was done in a reaction flask with a stopper. The stopper contained an inlet line for $\mathrm{HCl}$, a vent, and a glass reference electrode. During the titration, the contents of the reaction flask were kept at $25^{\circ} \mathrm{C}$ in a water bath and agitated by a magnetic stir bar. $\mathrm{HCl}(0.5 \mathrm{M})$ was added to a known volume of sample in the vented reaction flask. The amount of acid added and the change in

potential from the glass reference electrode were entered in a calculator program. The program "Alkreg" written by Larry Schemel calculated the end point of the titration. The end point corresponds to the stoichiometric equivalence point for the neutralization of all bases present, primarily carbonate species.

\section{Specific Conductance}

Conductivity was measured with a Cole-Parmer model 19820-00 conductivity meter. Samples were kept at $25^{\circ} \mathrm{C}$ in a water bath during measurement. Instrumental drift was corrected for by analyzing blanks and standards between sample sets. Specific conductance was calculated by adjusting conductivity measurements taken at $25^{\circ} \mathrm{C}$ with the results of a standard curve (Shelton, 1994).

\section{Total Suspended Solids Concentration}

The total suspended solids concentration was determined in the laboratory. During the collection-day processing the first filter used for each site was preweighed, this filter received $300 \mathrm{ml}$ of water sample. The filter was then stored in a desiccator and weighed biweekly to a constant weight. The TSS concentration was calculated by dividing the increased weight of the filter by $300 \mathrm{ml}$. Values are reported to $+/-0.1 \mathrm{mg} / \mathrm{L}$, based on the accuracy of the analytical balance. 


\section{DATA DESCRIPTION}

Temporal and spatial variability was documented in the data collected from Permanente and Saratoga Creeks. Table 1 and figure 2 display discharge variability. Temporal variability is displayed in figures 3 through 11 . Spatial variability is displayed in figures 12 through 20 . Water quality data are presented in tables 2 through 18 . Ion and total suspended solids concentrations are presented in milligrams per liter $(\mathrm{mg} / \mathrm{L})$, alkalinity in milliequivalents per liter $(\mathrm{meq} / \mathrm{L}), \mathrm{pH}$ in $\mathrm{pH}$ units, specific conductance in microsemens per centimeter $(\mathrm{us} / \mathrm{cm})$, and temperature in degrees celsius $\left({ }^{\circ} \mathrm{C}\right)$. The appropriate number of significant digits used to present data throughout this report were based on the precision and reliability of the methods used for analyses.

\section{Discharge Variability}

Discharge varied throughout the water year, often changing quickly during storms (fig. 2). Table 1 and figure 2 illustrate discharge level as samples were taken. Peak flow in Permanente Creek was 162 cubic feet per second $\left(\mathrm{ft}^{3} / \mathrm{s}\right)$ while the median was $6.95 \mathrm{ft}^{3} / \mathrm{s}$. Peak flow in Saratoga Creek was $543 \mathrm{ft}^{3} / \mathrm{s}$ while the median was $1.7 \mathrm{ft}^{3} / \mathrm{s}$.

Surface flow was present in the creeks during each sampling period at all sites, except for at PR2 on October 1, 1996, August 15, 1997, and September 19, 1997. Discharge was zero at the Permanente gage on these dates. The stage at PR3 was noted to usually be lower and to not fluctuate as much between site visits as at PR2 or PR1.

\section{Temporal Variability}

Analyte concentrations at SA3 and PR1 varied throughout the water year. Figures 3 through 11 display a generally negative relationship between discharge and analyte concentration. PR1 data was used for these plots because the site is downstream from the confluence of Permanente and West Fork Permanente Creek and nearest to the Permanente Creek gaging station. SA3 data was used for these plots because the site is downstream from the confluence of Booker and Mc Elroy Creek with Saratoga Creek, upstream from the impact of urbanization on Saratoga Creek (fig. 1), and nearest to the Saratoga Creek gaging station. 


\section{Spatial Variability}

Figures 12 through 20 display points for all water year 1997 water quality data at each site, with lines of: median data values for the water year, median data values for the high flow periods of the water year (November 20, 1996 through March 3, 1997), and median data values for the base flow periods of the water year (October 1, 1996 through November 19, 1996 and March 4, 1997 through September 30, 1997).

In Saratoga Creek the median values for specific conductance, alkalinity, sulfate, calcium and magnesium concentrations increase from SA6 to SA5, decrease from SA5 to SA4, increase from SA4 downstream through SA2, then sharply drop by SA1. Median values for sodium and chloride follow a spatial pattern similar to the other constituents in Saratoga Creek; however, values increase in concentration from SA2 downstream to SA1. High-flow median values tend to be lower and change less between sites than water year median values. Low-flow median values tend to be higher and change more between sites than water year median values. 


\section{REFERENCES}

Fishman, M.J. and Friedman, L.C., eds., 1989, Methods for determination of inorganic substances in water and fluvial sediments: U.S. Geological Survey Techniques of WaterResources Investigations, book 5, chap. A1, 545 p.

Gran, Gunnar, 1952, Determination of the equivalence point in potentiometric titrations, Part II: The Analyst, v. 77, p. 661-671.

Nolan, K.M. and Hill, B.R., 1989, Effects of limestone quarrying and cement-plant operations on runoff and sediment yields in the upper Permanente Creek basin, Santa Clara County, California: U.S. Geological Survey Open-File Report 89-4130, 48 p.

Shelton, L.R., 1994, Field guide for collecting and processing stream-water samples for the National Water-Quality Assessment program: U.S. Geological Survey Open-File Report 94-455, 40 p.

Ward, J.R. and Harr, C.A., 1990, Methods for collection and processing of surface-water and bed-material samples for physical and chemical analysis: U.S. Geological Survey Open-File Report 90-140, 71 p. 

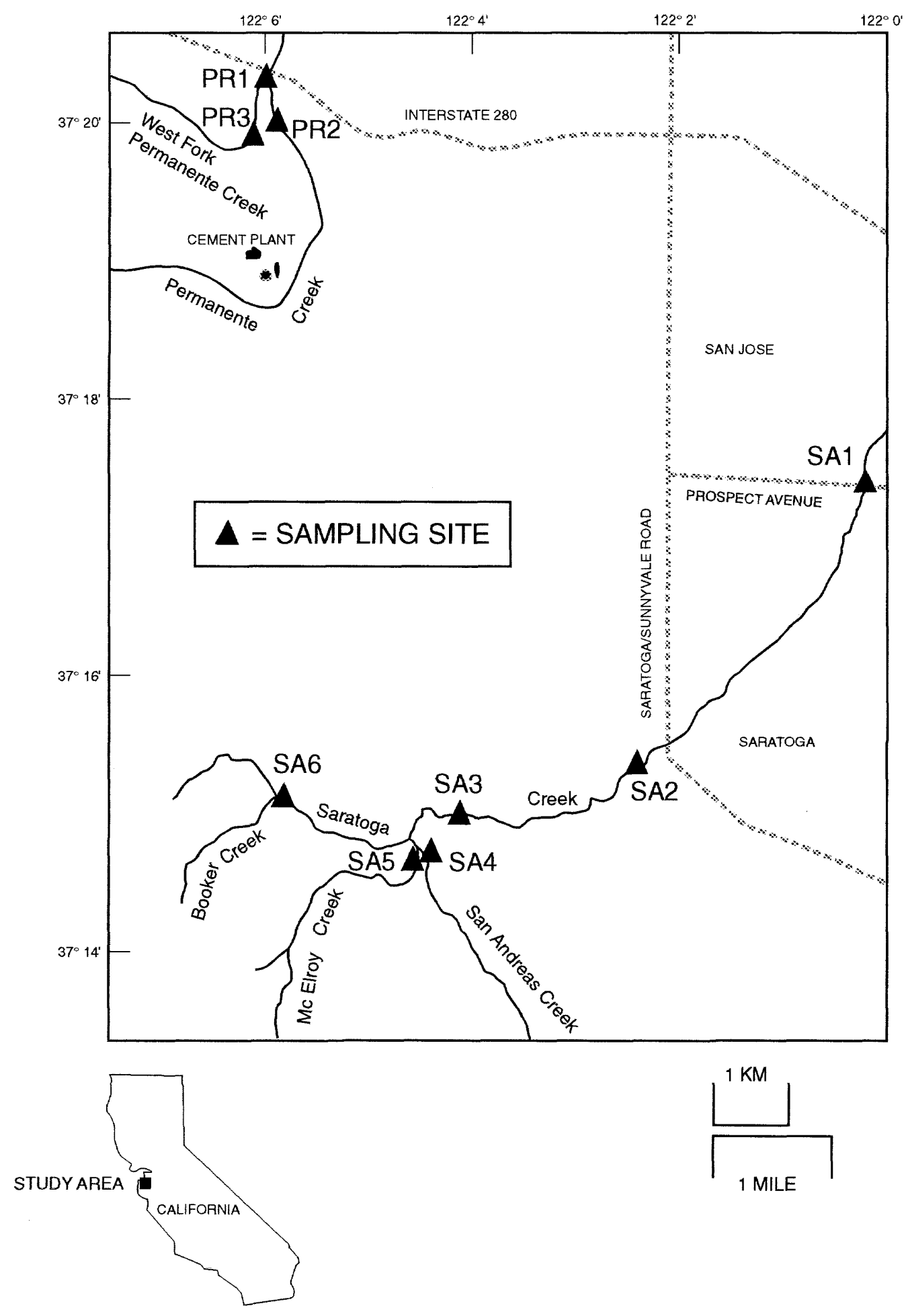

Figure 1. Location of study area 
Table 1. Permanente and Saratoga Creek discharge on sampling dates $\left[\mathrm{ft}^{3} / \mathrm{s}\right.$, cubic feet per second ]

\begin{tabular}{lll}
\hline Date & $\begin{array}{l}\text { Permanente Creek } \\
\text { Discharge }\left(\mathrm{ft}^{3} / \mathrm{s}\right)\end{array}$ & $\begin{array}{l}\text { Saratoga Creek } \\
\text { Discharge }\left(\mathrm{ft}^{3} / \mathrm{s}\right)\end{array}$ \\
& & \\
& & \\
& & \\
$10 / 1 / 96$ & 0 & 1.5 \\
$10 / 24 / 96$ & 0 & 1.6 \\
$11 / 5 / 96$ & 0 & 1.6 \\
$11 / 20 / 96$ & 2.2 & 6.5 \\
$12 / 3 / 96$ & 0.28 & 0.47 \\
$12 / 12 / 96$ & 9.8 & 32 \\
$1 / 2 / 97$ & 142 & 349 \\
$1 / 13 / 97$ & 16 & 17 \\
$1 / 27 / 97$ & 86 & 139 \\
$2 / 5 / 97$ & 29 & 33 \\
$3 / 3 / 97$ & 12 & 8.3 \\
$4 / 1 / 97$ & 9.4 & 2.8 \\
$5 / 2 / 97$ & 13 & 1.6 \\
$6 / 10 / 97$ & 0.15 & 3.2 \\
$7 / 8 / 97$ & 0 & 0.61 \\
$8 / 15 / 97$ & 0 & 0.49 \\
$9 / 18 / 97$ & 0 & 0.16 \\
& &
\end{tabular}




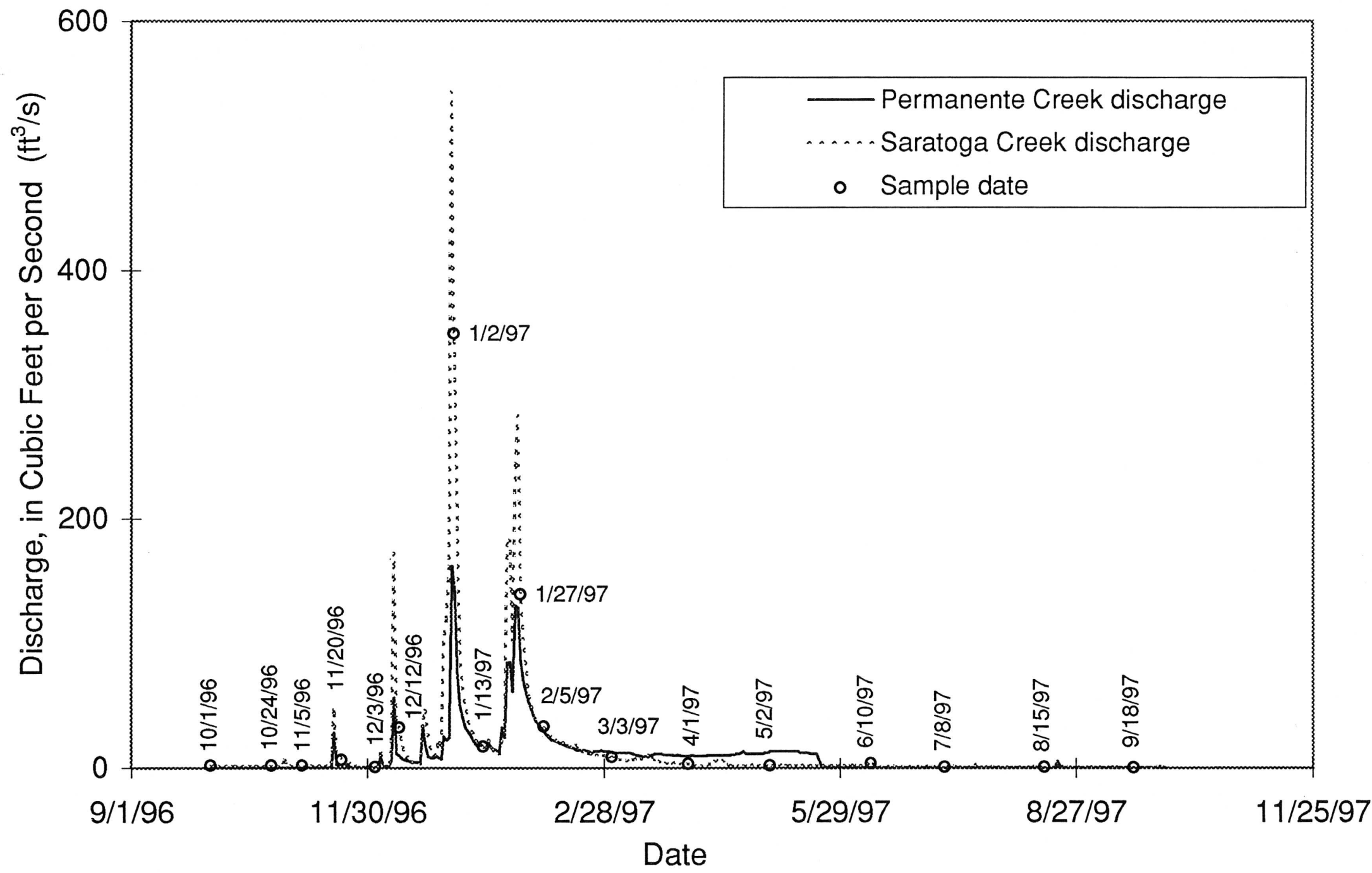

Figure 2. Permanente and Saratoga Creek hydrograph for water year 1997 


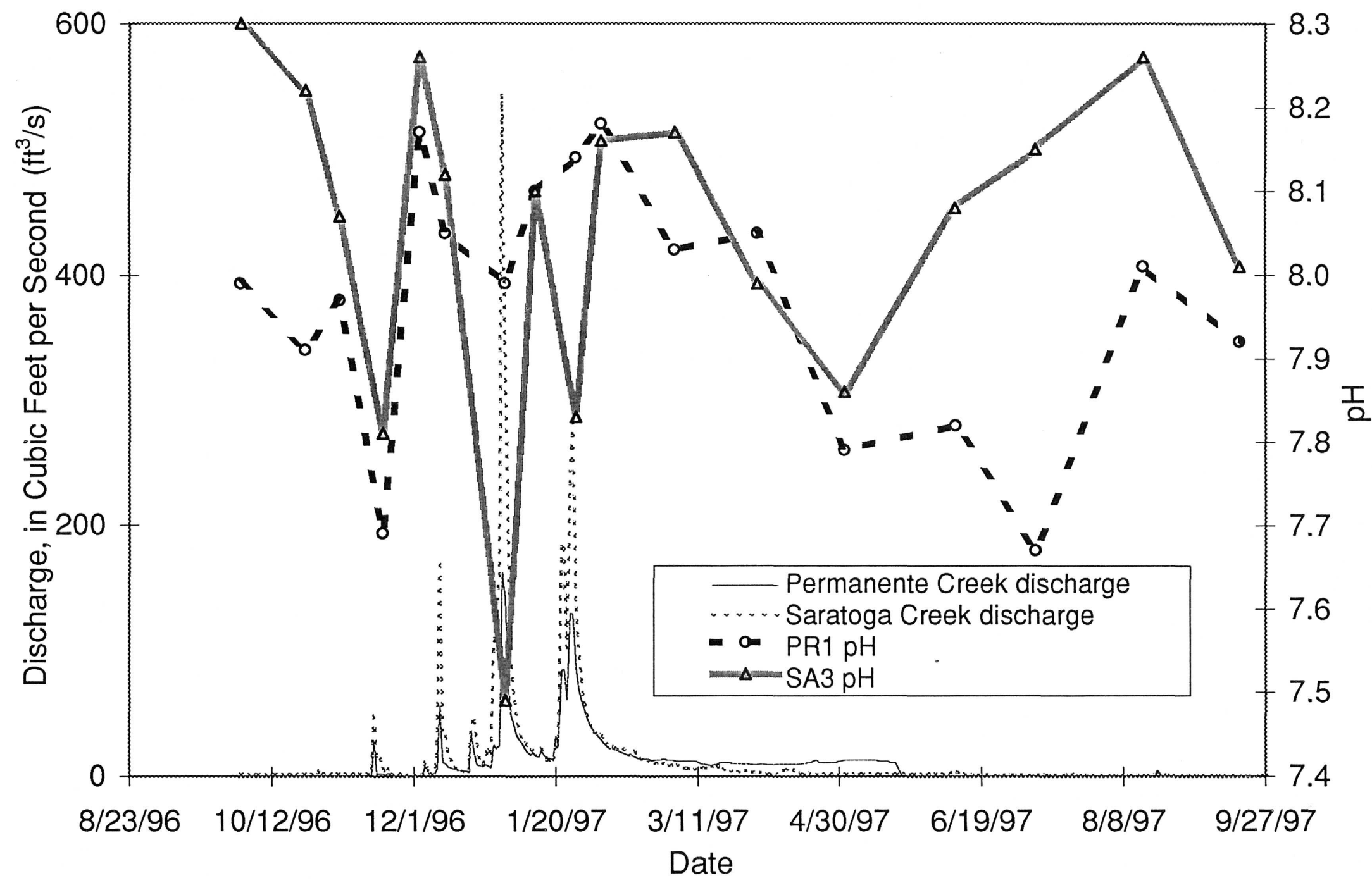

Figure 3. Temporal variability of $\mathrm{pH}$ at PR1 and SA3, hydrograph of Permanente and Saratoga Creeks 


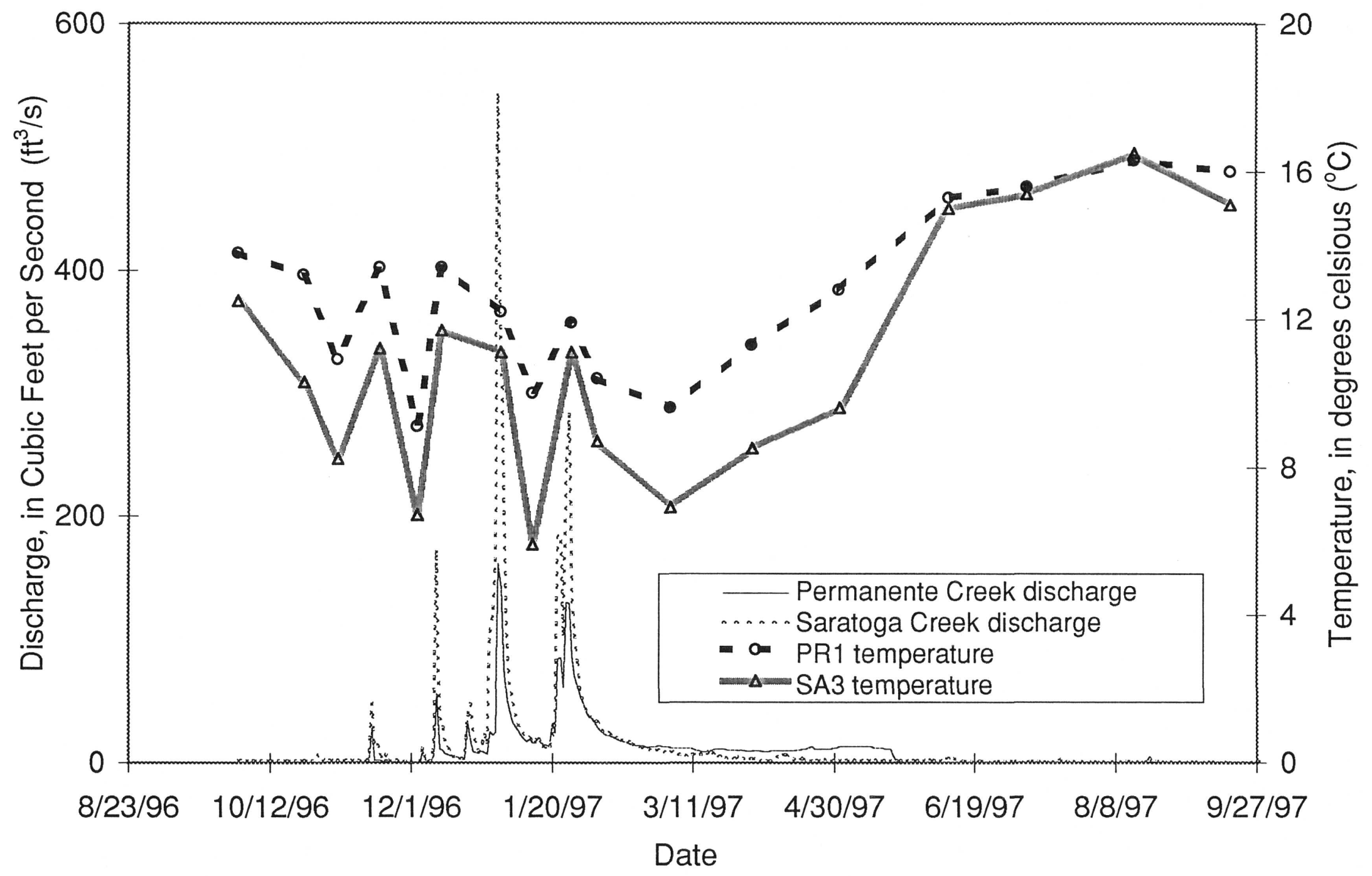

Figure 4. Temporal variability of temperature at PR1 and SA3, hydrograph of Permanente and Saratoga Creeks 


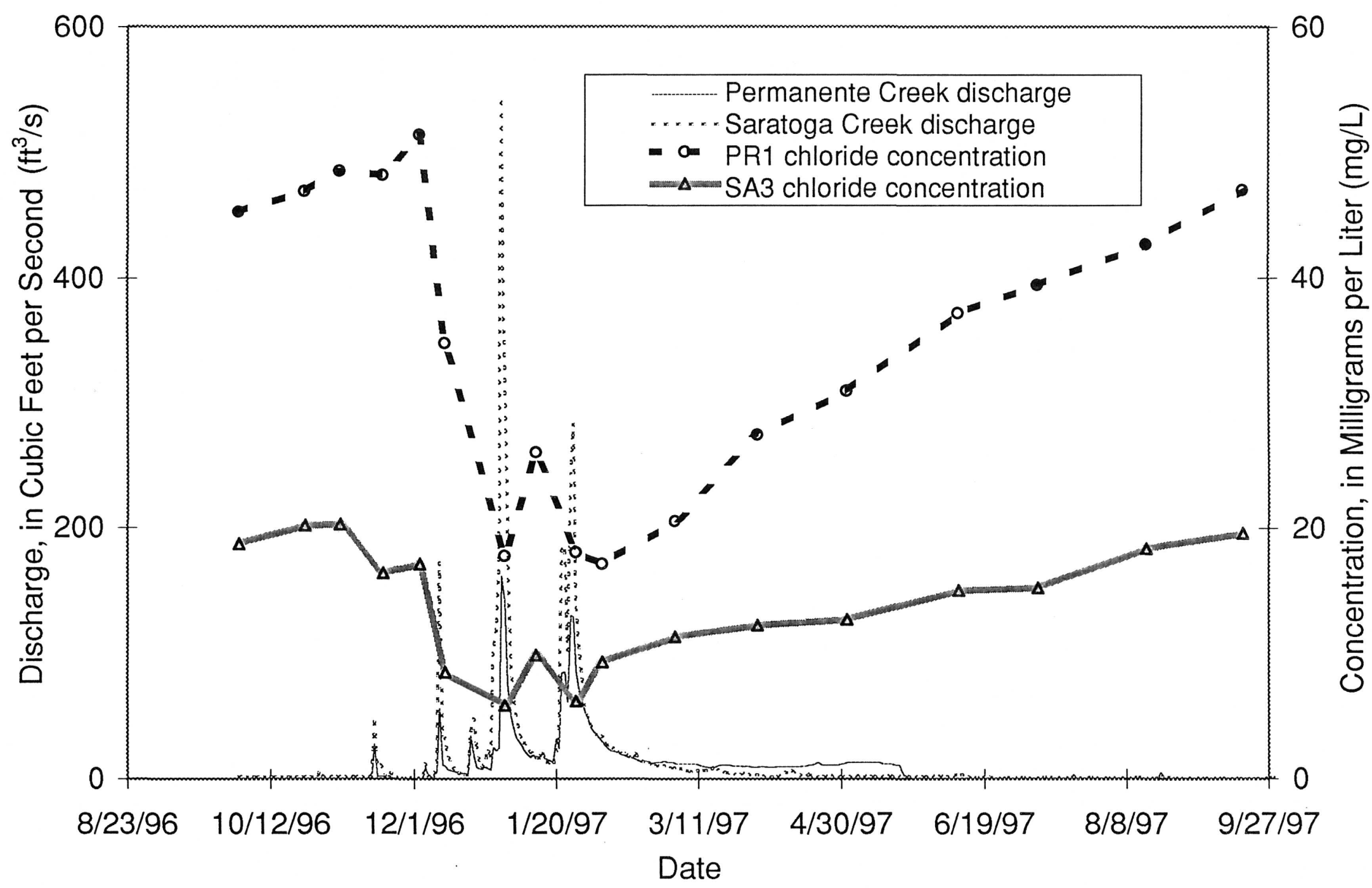

Figure 5. Temporal variability of chloride concentration at PR1 and SA3, hydrograph of Permanente and Saratoga Creeks 


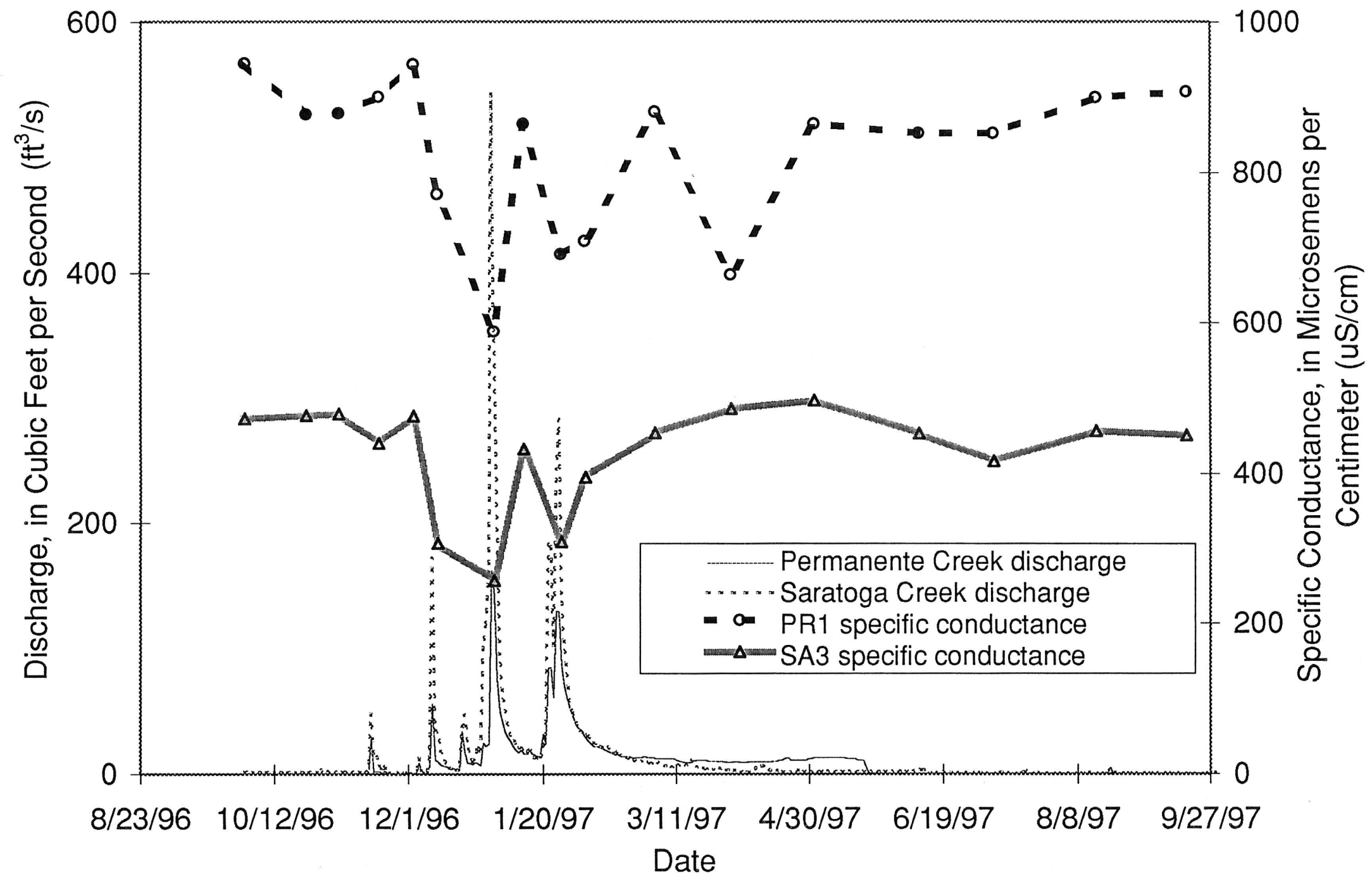

Figure 6. Temporal variability of specific conductance at PR1 and SA3, hydrograph of Permanente and Saratoga Creeks 


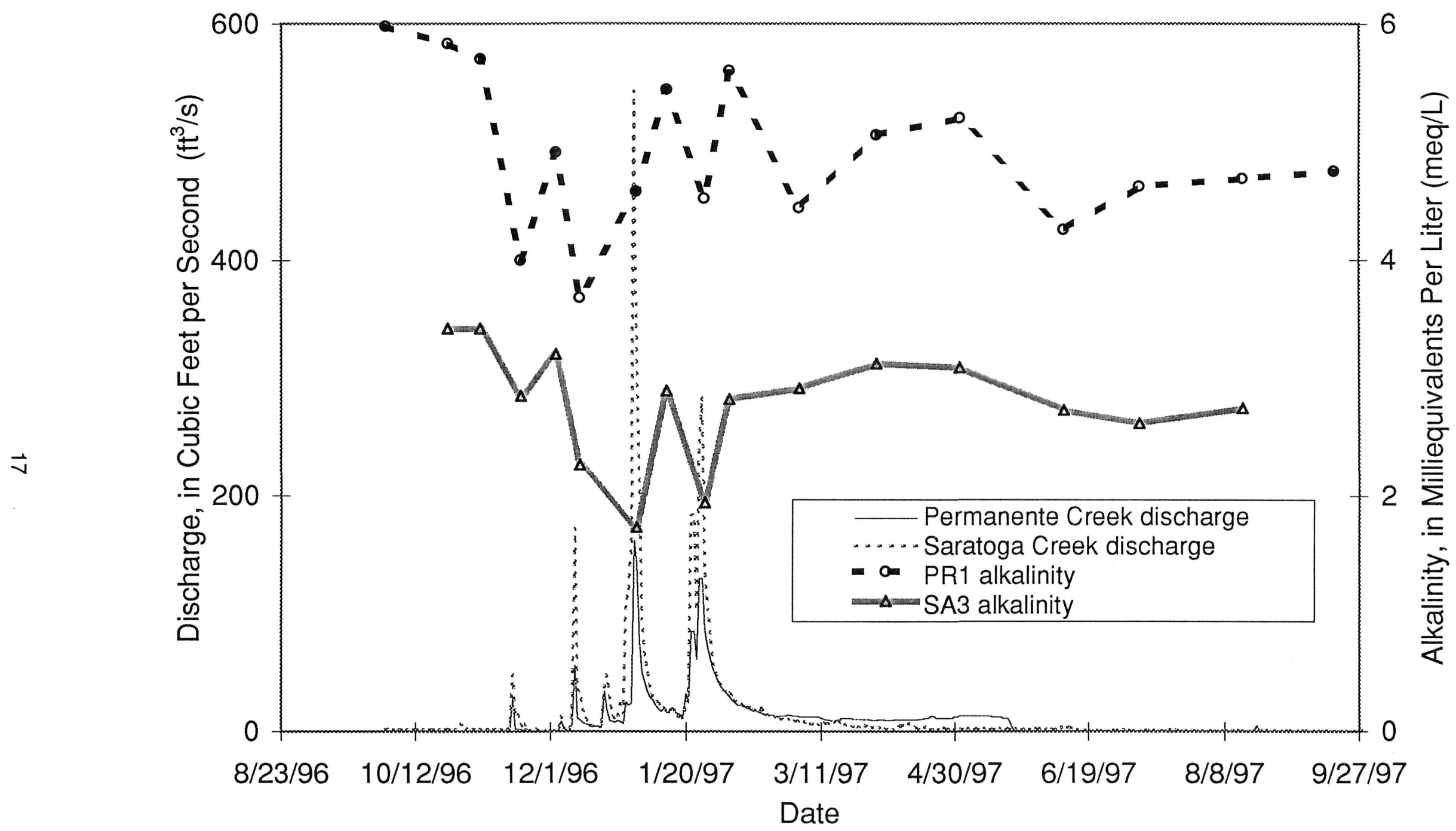

Figure 7. Temporal variability of alkalinity at PR1 and SA3, hydrograph of Permanente and Saratoga Creeks 


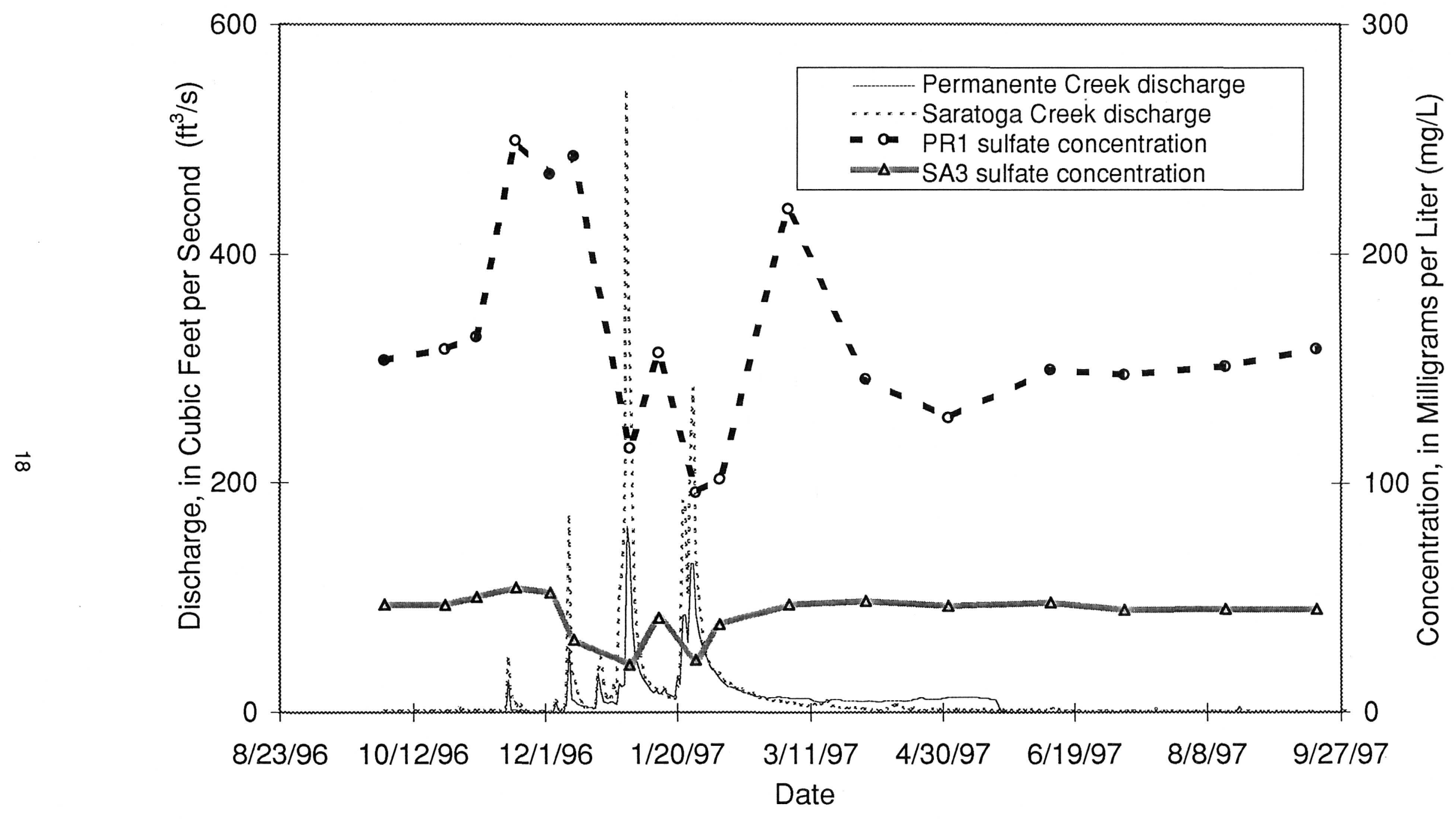

Figure 8. Temporal variability of sulfate concentration at PR1 and SA3, hydrograph of Permanente and Saratoga Creeks 


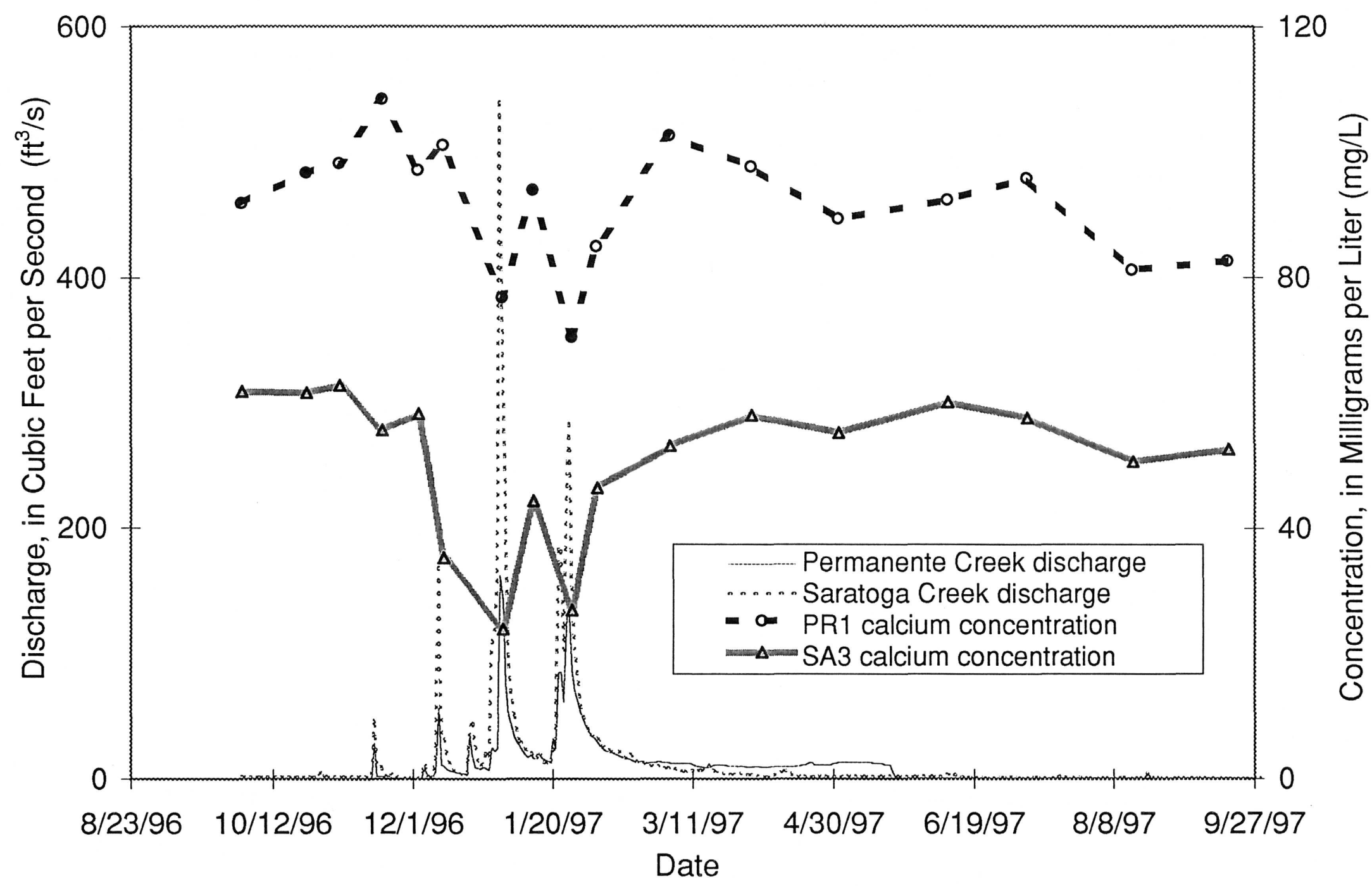

Figure 9. Temporal variability of calcium concentration at PR1 and SA3, hydrograph of Permanente and Saratoga Creeks 


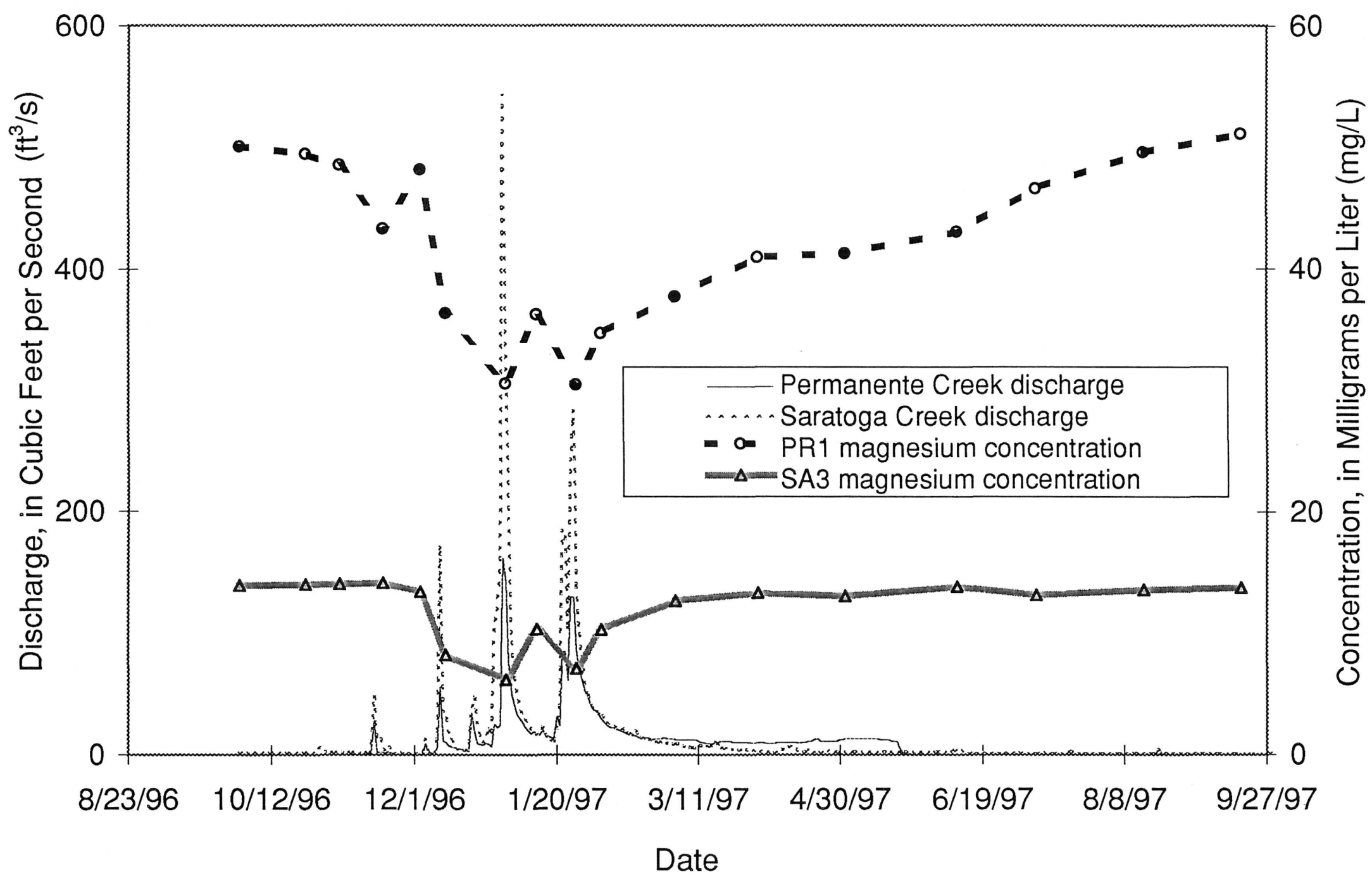

Figure 10. Temporal variability of magnesium concentration at PR1 and SA3, hydrograph of Permanente and Saratoga Creeks 


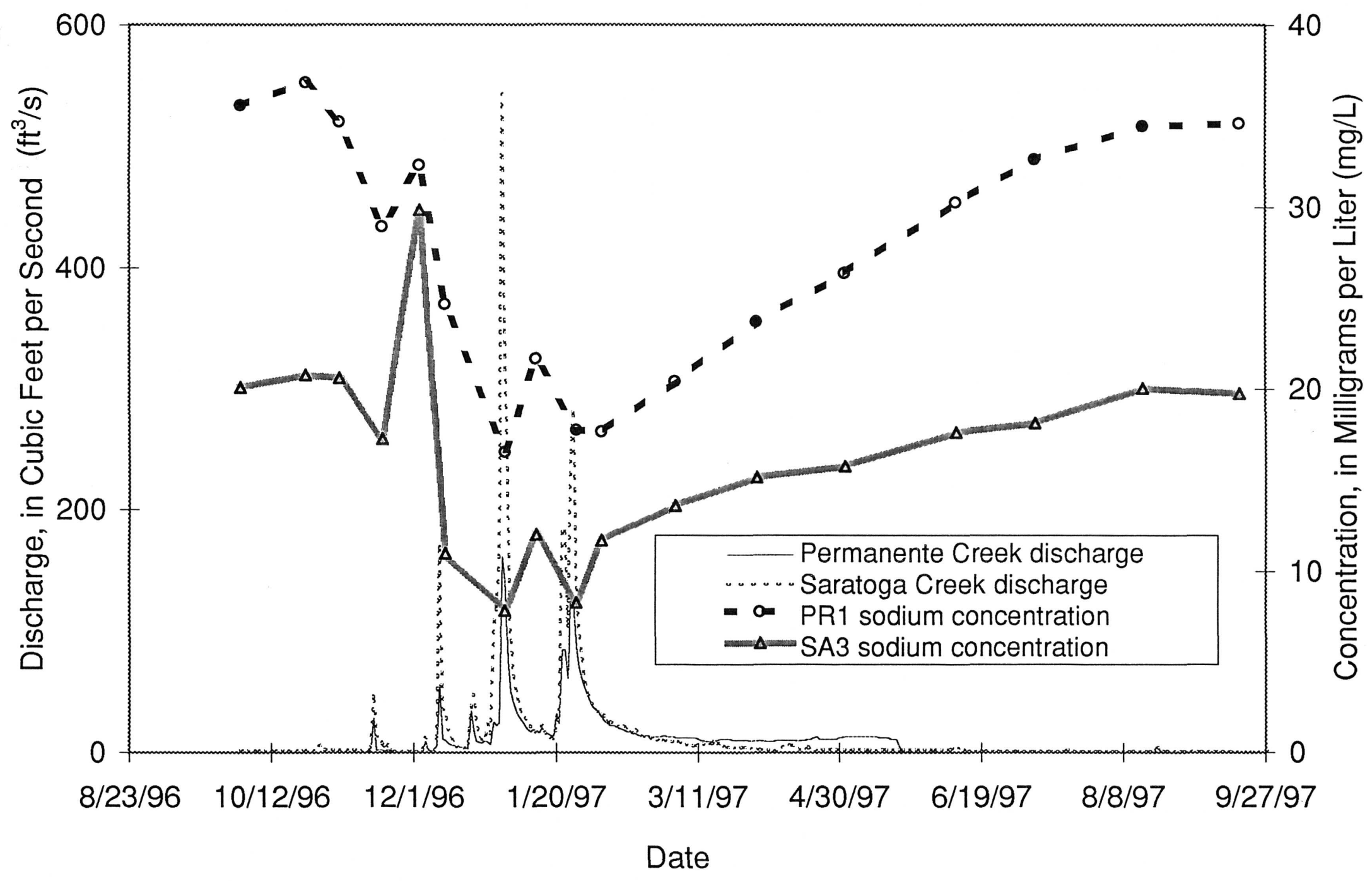

Figure 11. Temporal variability of sodium concentration at PR1 and SA3, hydrograph of Permanente and Saratoga Creeks 


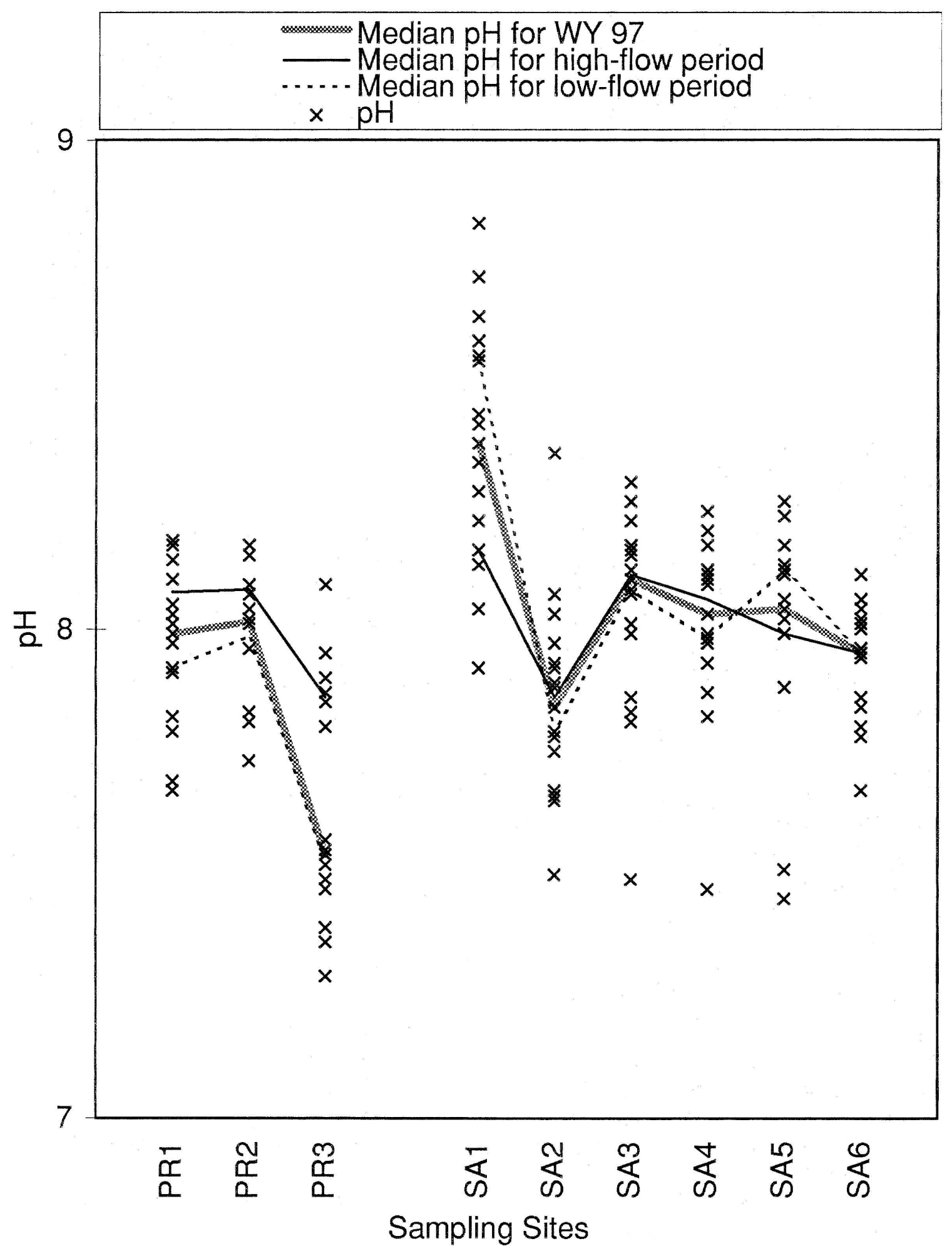

Figure 12. Spatial variability of $\mathrm{pH}$ 


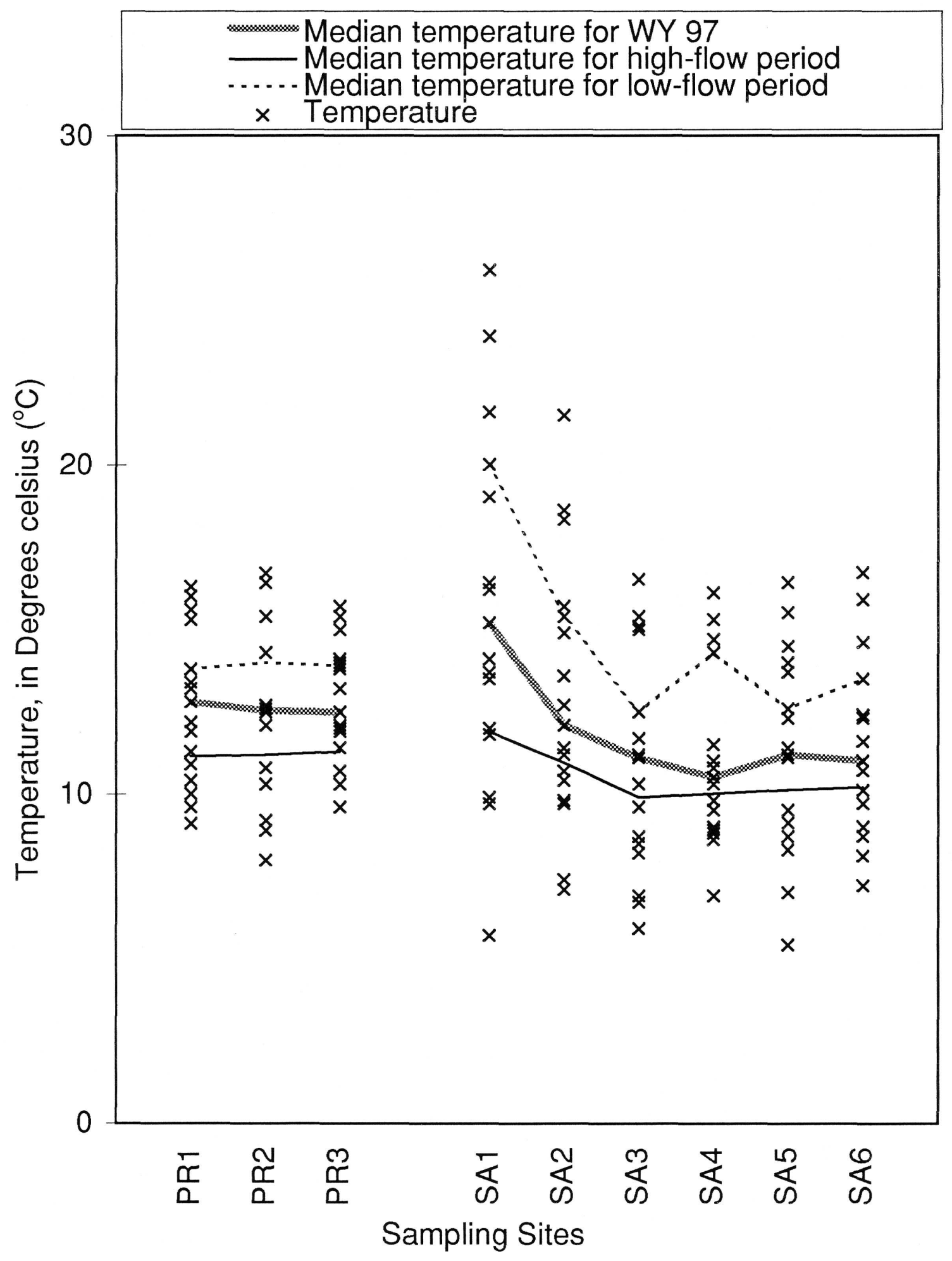

Figure 13. Spatial variability of Temperature 


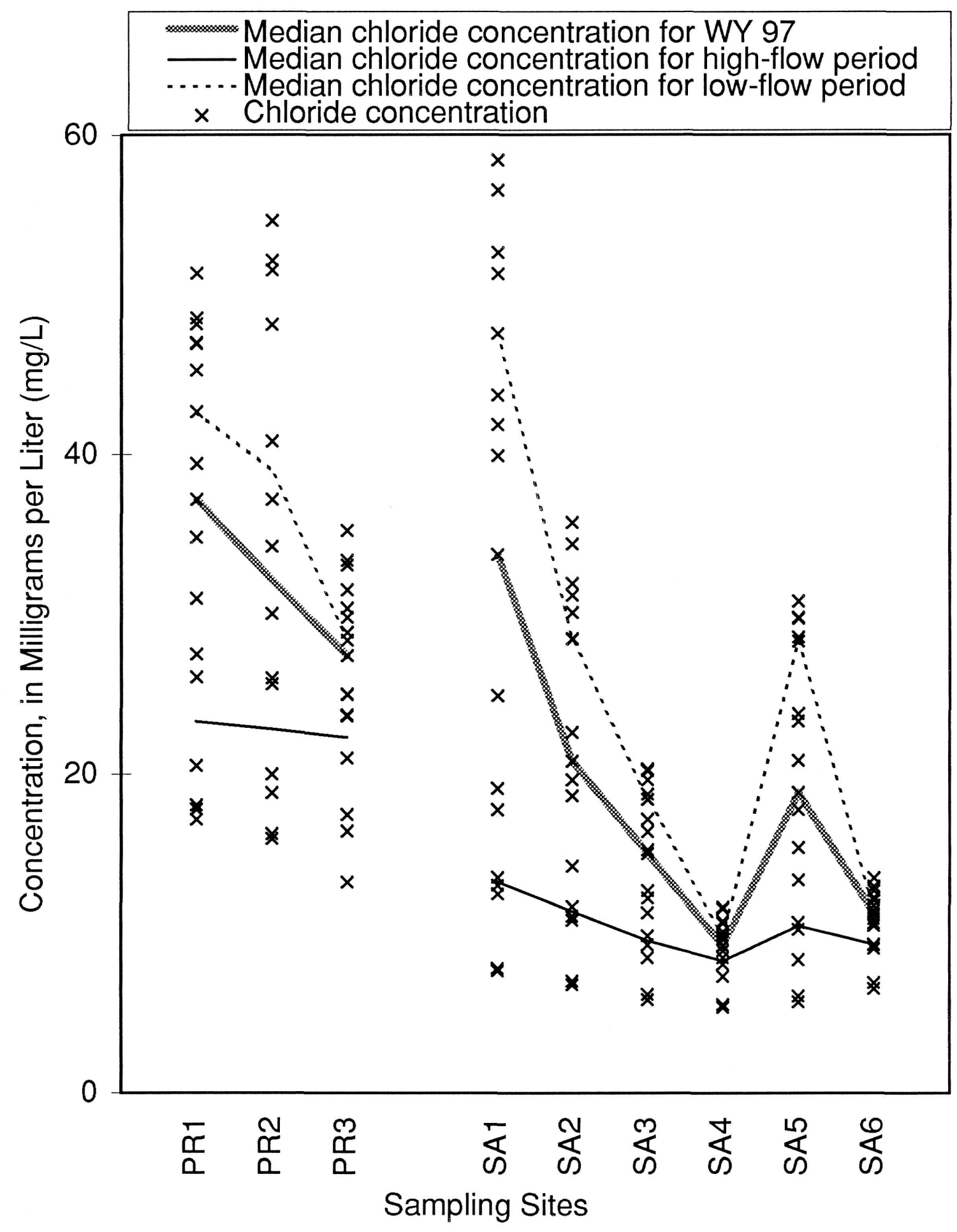

Figure 14. Spatial variability of chloride concentration 


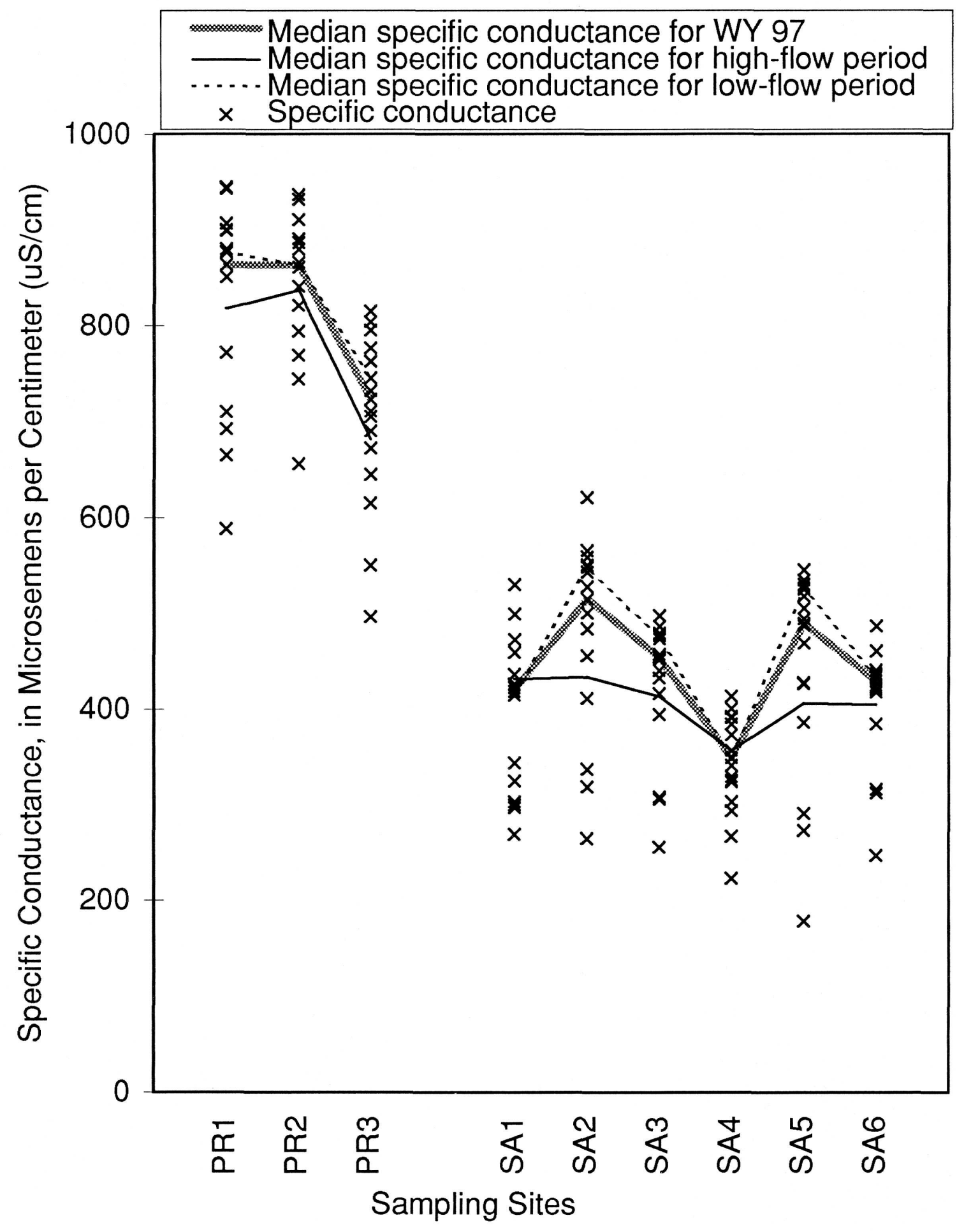

Figure 15. Spatial variability of specific conductance 


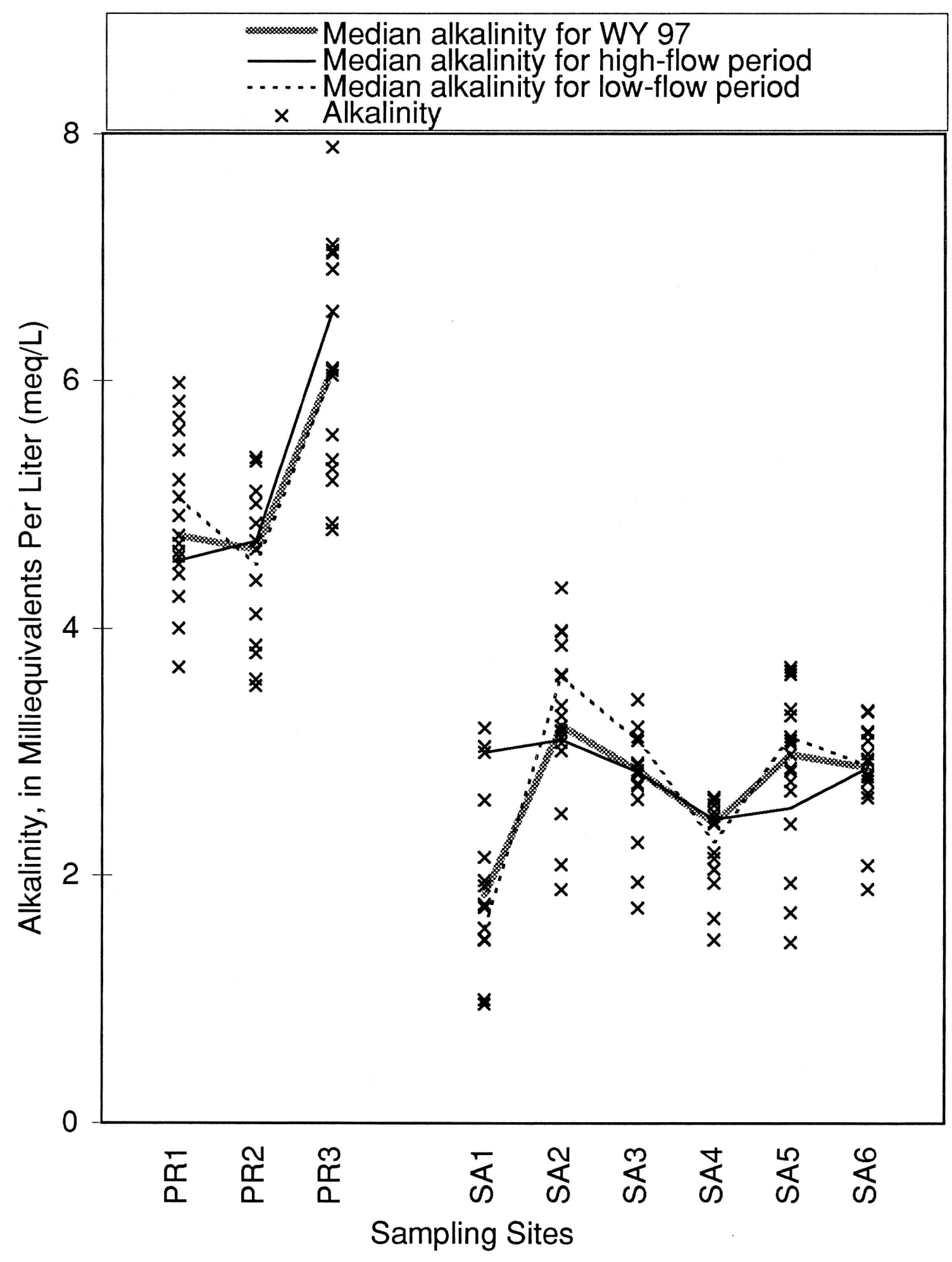

Figure 16. Spatial variability of alkalinity 


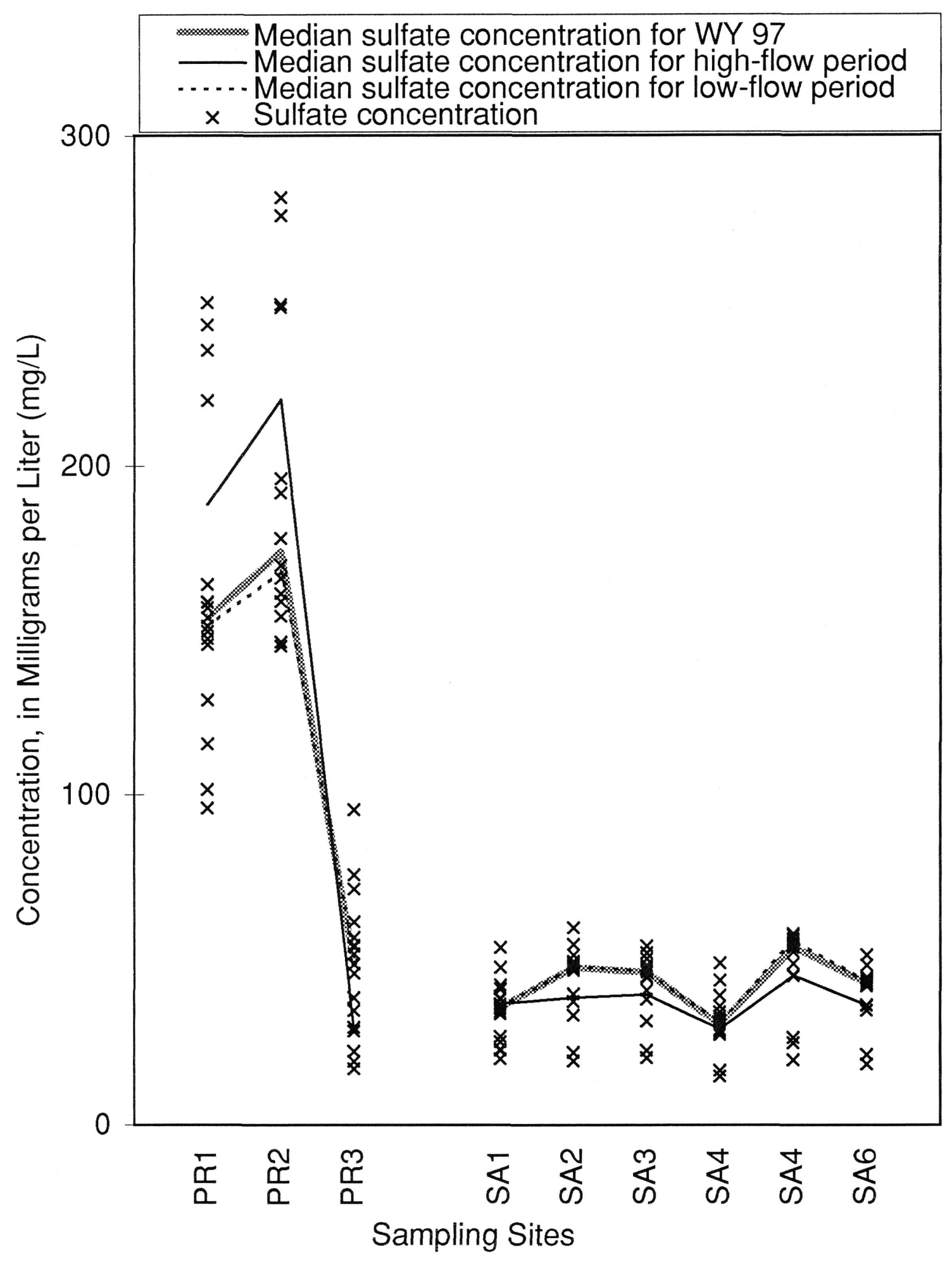

Figure 17. Spatial variability of sulfate concentration 


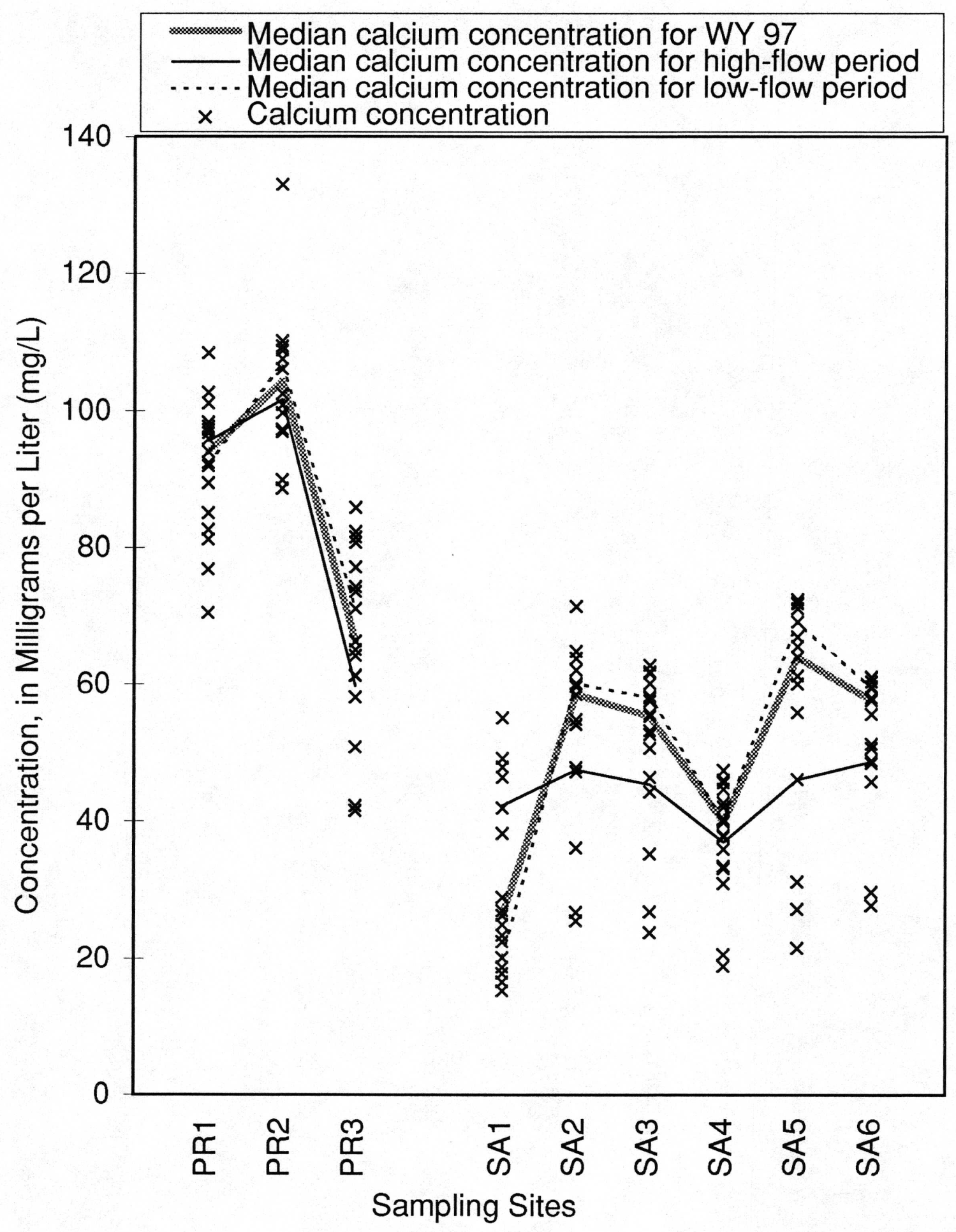

Figure 18. Spatial variability of calcium concentration 


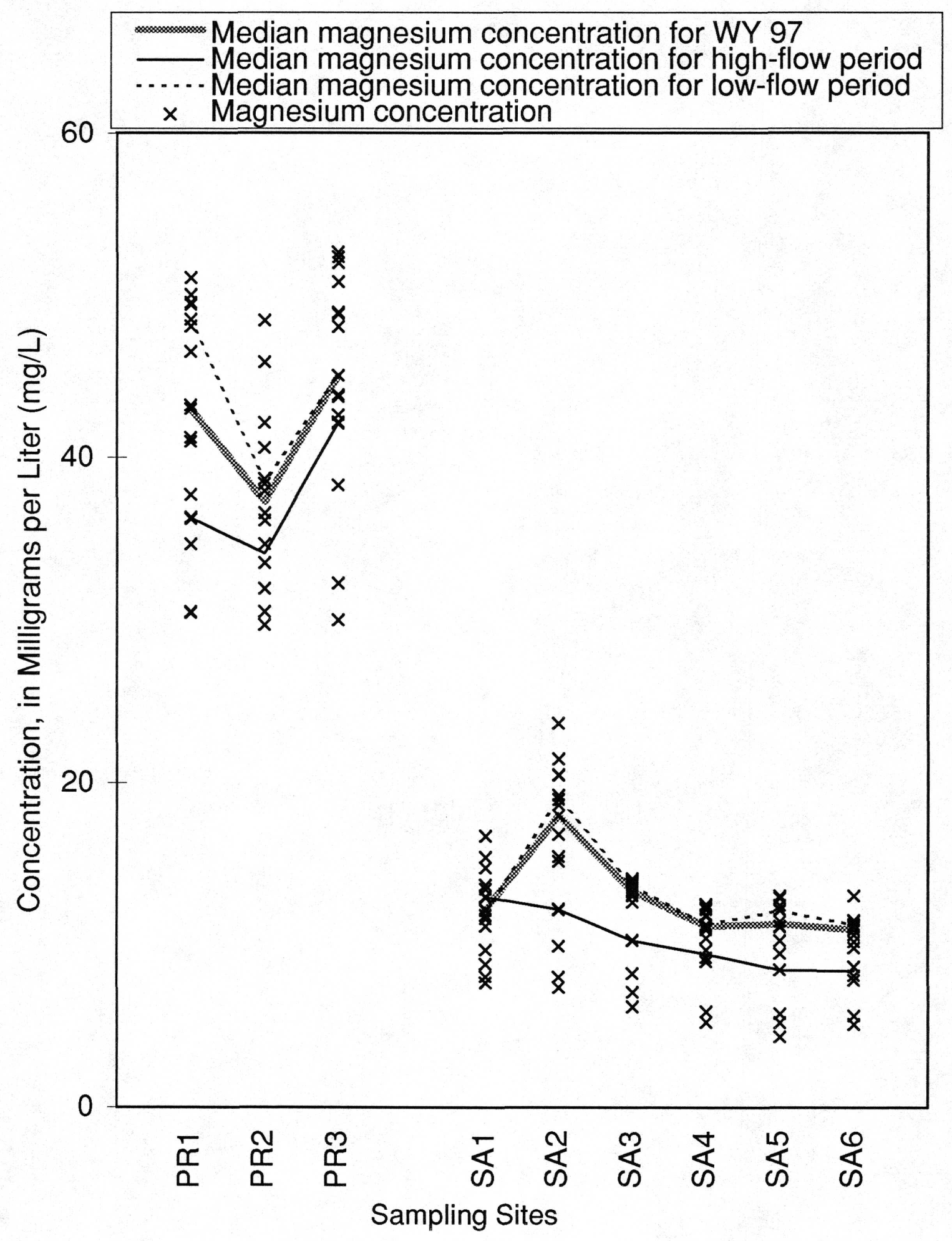

Figure 19. Spatial variability of magnesium concentration 


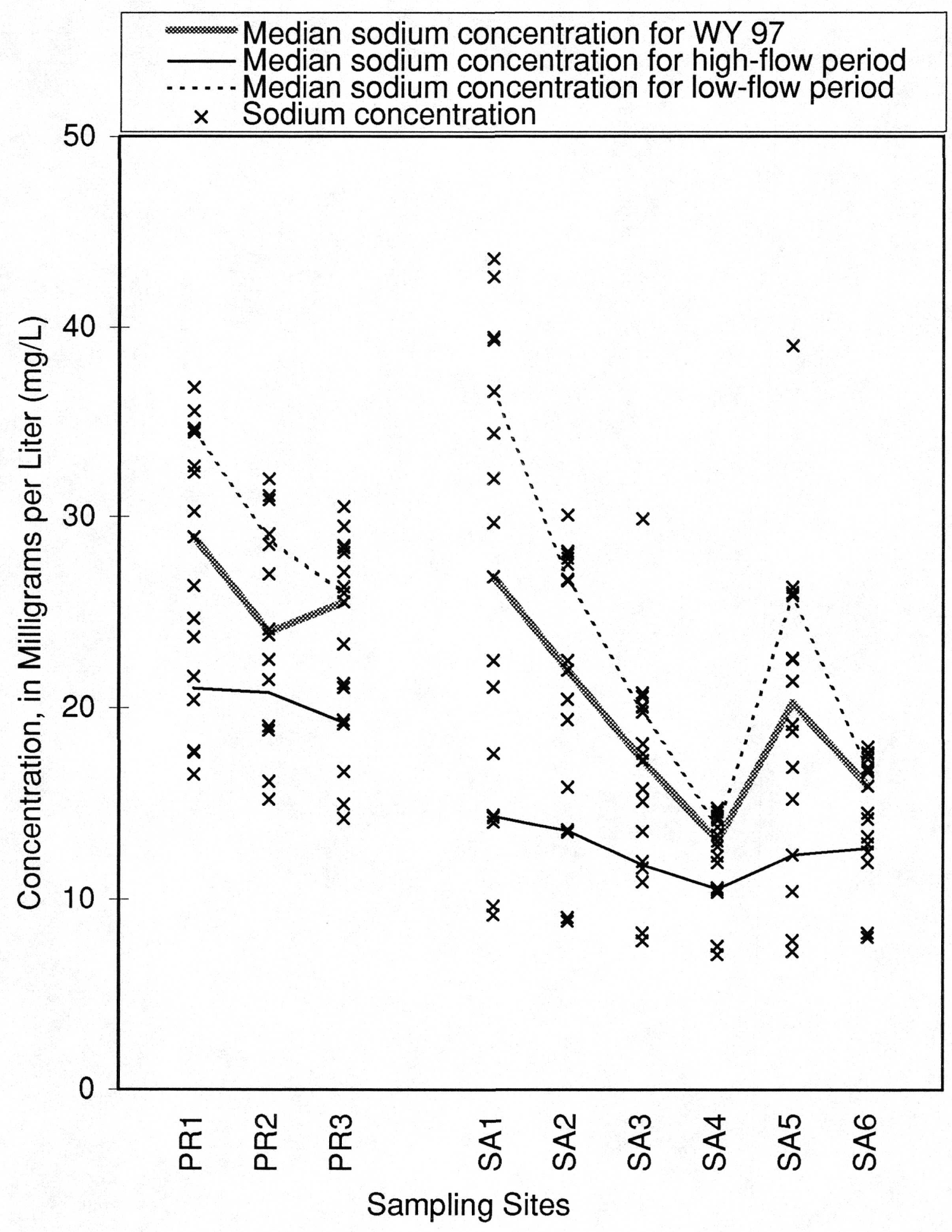

Figure 20. Spatial variability of sodium concentration 
Table 2. Measurements from Permanente and Saratoga Creek october 1, 1996

Site locations.-- See Figure 1. and Description of study Area

\begin{tabular}{|c|c|c|c|c|c|c|c|c|c|}
\hline \multirow[b]{2}{*}{ MEASUREMENT } & \multicolumn{9}{|c|}{$------------------------S I T E-------------------------$} \\
\hline & PR1 & PR2* & * $\quad$ PR3 & SAI & SA2 & SA3 & SA4 & SA5 & SA6 \\
\hline $\mathrm{pH}$ & 7.99 & --- & 7.54 & 8.72 & 8.03 & 8.30 & 8.24 & 8.04 & 8.11 \\
\hline TEMP (C) & 13.8 & $-\cdots$ & 13.9 & 20.0 & 13.6 & 12.5 & 14.3 & 12.6 & 13.5 \\
\hline COND (us/cm) & 950 & --- & 800 & 420 & 550 & 470 & 360 & 540 & 430 \\
\hline TSS (mg/L) & 0.0 & --- & 0.0 & 0.0 & 0.0 & 0.0 & 0.0 & 0.0 & 0.0 \\
\hline ALK (meq/L) & 5.98 & --- & 6.90 & 1.75 & 3.86 & --- & 2.57 & 3.65 & -- \\
\hline $\mathrm{Cl}(\mathrm{mg} / \mathrm{L})$ & 45 & --- & 30 & 51 & 28 & 19 & 11 & 29 & 11 \\
\hline $\mathrm{SO} 4$ (mg/L) & 154 & --- & 54 & 37 & 49 & 47 & 33 & 54 & 43 \\
\hline $\mathrm{Ca}(\mathrm{mg} / \mathrm{L})$ & 92 & --- & 77 & 23 & 64 & 62 & 40 & 72 & 60 \\
\hline $\operatorname{Mg}(\mathrm{mg} / \mathrm{L})$ & 50 & --- & 49 & 13 & 19 & 14 & 12 & 12 & 11 \\
\hline $\mathrm{Na} \quad(\mathrm{mg} / \mathrm{L})$ & 36 & --- & 27 & 40 & 27 & 20 & 14 & 26 & 17 \\
\hline
\end{tabular}

Table 3. Measurements from Permanente and Saratoga Creek October 24, 1996

Site locations.-- See Figure 1. and Description of Study Area

\begin{tabular}{|c|c|c|c|c|c|c|c|c|c|}
\hline MEASUREMENT & PR1 & PR2 & PR3 & SA1 & $\mathrm{SA} 2$ & SA3 & SA4 & SA 5 & SA 6 \\
\hline $\mathrm{pH}$ & 7.91 & 8.02 & 7.52 & 8.44 & 7.67 & 8.22 & 8.11 & 8.26 & 8.11 \\
\hline TEMP (C) & 13.2 & 15.4 & 13.8 & 19.0 & 15.4 & 10.3 & 10.3 & 11.2 & 12.3 \\
\hline COND (uS/ cm) & 880 & 870 & 760 & 420 & 530 & 480 & 320 & 530 & 430 \\
\hline TSS (mg/L) & 3.0 & 0.7 & 0.0 & 2.7 & 0.0 & 0.0 & 0.0 & 0.0 & 0.0 \\
\hline ALK (meq/L) & 5.83 & 5.38 & 7.03 & 1.48 & 3.98 & 3.42 & --- & 3.68 & 3.33 \\
\hline $\mathrm{Cl}(\mathrm{mg} / \mathrm{L})$ & 47 & 52 & 30 & 58 & 30 & 20 & 11 & 30 & 12 \\
\hline $\mathrm{SO} 4 \quad(\mathrm{mg} / \mathrm{L})$ & 158 & 166 & 57 & 37 & 48 & 47 & 31 & 54 & 43 \\
\hline $\mathrm{Ca}(\mathrm{mg} / \mathrm{L})$ & 97 & 108 & 81 & 19 & 65 & 62 & 40 & 72 & 59 \\
\hline $\operatorname{Mg}(\mathrm{mg} / \mathrm{L})$ & 49 & 41 & 49 & 12 & 19 & 14 & 11 & 12 & 11 \\
\hline $\mathrm{Na}(\mathrm{mg} / \mathrm{L})$ & 37 & 31 & 29 & 44 & 28 & 21 & 14 & 26 & 18 \\
\hline
\end{tabular}


Table 4. Measurements from Permanente and Saratoga Creek November 5, 1996

Site locations.-- See Figure 1. and Description of Study Area

\begin{tabular}{|c|c|c|c|c|c|c|c|c|c|}
\hline MEASUREMENT & PRI & PR2 & PR3 & SA1 & SA2 & SA3 & SA4 & SA5 & SA6 \\
\hline $\mathrm{pH}$ & 7.97 & 8.01 & 7.57 & 8.28 & 7.89 & 8.07 & 7.82 & 8.17 & 7.84 \\
\hline TEMP (C) & 10.9 & 12.5 & 11.4 & 16.4 & 9.8 & 8.2 & 8.9 & 8.7 & 9.0 \\
\hline COND (uS/ cm) & 880 & 890 & 780 & 410 & 550 & 480 & 380 & 520 & 440 \\
\hline TSS (mg/L) & 0.0 & 0.0 & 0.0 & 3.3 & 1.0 & 0.0 & 0.0 & 0.0 & 0.0 \\
\hline ALK (meq/L) & 5.70 & 5.35 & 7.10 & 1.47 & 3.97 & 3.42 & 2.63 & 3.62 & 3.32 \\
\hline $\mathrm{Cl}(\mathrm{mg} / \mathrm{L})$ & 49 & 55 & 32 & 57 & 32 & 20 & 12 & 30 & 12 \\
\hline $\mathrm{SO} 4$ (mg/L) & 160 & 180 & 61 & 34 & 51 & 50 & 39 & 55 & 45 \\
\hline $\mathrm{Ca}$ (mg/L) & 98 & 110 & 81 & 18 & 65 & 63 & 46 & 71 & 61 \\
\hline $\operatorname{Mg}(\mathrm{mg} / \mathrm{L})$ & 49 & 49 & 51 & 11 & 19 & 14 & 13 & 12 & 11 \\
\hline $\mathrm{Na} \quad(\mathrm{mg} / \mathrm{L})$ & 35 & 31 & 28 & 43 & 28 & 21 & 15 & 26 & 17 \\
\hline
\end{tabular}

Table 5. Measurements from Permanente and Saratoga Creek November 20, 1996 Site locations.-- See Figure 1. and Description of Study Area

\begin{tabular}{|c|c|c|c|c|c|c|c|c|c|}
\hline MEASUREMENT & PR1 & PR2 & PR3 & SA1 & SA2 & $\mathrm{SA} 3$ & SA4 & SA 5 & SA6 \\
\hline $\mathrm{pH}$ & 7.69 & 7.83 & 7.39 & 8.22 & 7.84 & 7.81 & 8.03 & 8.23 & 8.02 \\
\hline TEMP (C) & 13.4 & 12.7 & 12.5 & 13.5 & 14.9 & 11.2 & 11.0 & 12.3 & 11.6 \\
\hline COND (us/cm) & 900 & 910 & 820 & 470 & 480 & 440 & 390 & 430 & 440 \\
\hline TSS (mg/L) & 2.3 & 5.0 & 0.0 & 4.3 & 2.0 & 3.0 & 0 & 9.7 & 3.0 \\
\hline ALK (meq/L) & 4.00 & 3.53 & 7.05 & 3.04 & 3.16 & 2.85 & 2.57 & 2.76 & 3.15 \\
\hline $\mathrm{Cl} \quad(\mathrm{mg} / \mathrm{L})$ & 48 & 48 & 33 & 25 & 23 & 16 & 12 & 19 & 13 \\
\hline $\mathrm{SO} 4(\mathrm{mg} / \mathrm{L})$ & 250 & 280 & 76 & 54 & 55 & 54 & 49 & 49 & 51 \\
\hline $\mathrm{Ca}$ (mg/L) & 110 & 110 & 74 & 55 & 58 & 56 & 47 & 56 & 61 \\
\hline $\operatorname{Mg}(\mathrm{mg} / \mathrm{L})$ & 43 & 42 & 53 & 15 & 15 & 14 & 12 & 9.5 & 13 \\
\hline $\mathrm{Na}(\mathrm{mg} / \mathrm{L})$ & 29 & 27 & 30 & 23 & 23 & 17 & 14 & 19 & 17 \\
\hline
\end{tabular}


Table 6. Measurements from Permanente and Saratoga Creek December 3, 1996

Site locations.-- See Figure 1. and Description of Study Area

\begin{tabular}{|c|c|c|c|c|c|c|c|c|c|}
\hline MEASUREMENT & PR1 & PR2 & PR3 & SA1 & SA2 & SA3 & SA4 & SA5 & SA6 \\
\hline $\mathrm{pH}$ & 8.17 & 8.07 & 7.80 & 8.38 & 7.65 & 8.26 & 8.20 & 8.02 & 8.04 \\
\hline TEMP (C) & 9.1 & 8.9 & 9.6 & 14.1 & 10.7 & 6.7 & 9.0 & 9.1 & 8.1 \\
\hline COND (us/cm) & 940 & 940 & 690 & 430 & 620 & 480 & 390 & 490 & 430 \\
\hline $\operatorname{TSS}(\mathrm{mg} / \mathrm{L})$ & 2.0 & 2.0 & 0.0 & 0.0 & 0.0 & 0.0 & 0.0 & 1.3 & 0.0 \\
\hline ALK $(\mathrm{meq} / \mathrm{L})$ & 4.91 & 4.71 & 7.05 & 1.95 & 4.33 & 3.20 & 2.63 & 3.34 & 3.16 \\
\hline $\mathrm{Cl}(\mathrm{mg} / \mathrm{L})$ & 51 & 52 & 33 & 44 & 36 & 17 & 12 & 23 & 13 \\
\hline $\mathrm{SO} 4 \quad(\mathrm{mg} / \mathrm{L})$ & 230 & 250 & 71 & 35 & 60 & 52 & 44 & 52 & 48 \\
\hline $\mathrm{Ca}$ (mg/L) & 97 & 110 & 82 & 23 & 71 & 58 & 46 & 67 & 58 \\
\hline $\operatorname{Mg} \quad(\mathrm{mg} / \mathrm{L})$ & 48 & 46 & 52 & 14 & 24 & 13 & 13 & 11 & 11 \\
\hline $\mathrm{Na}$ (mg/L) & 32 & 32 & 28 & 34 & 30 & 30 & 15 & 23 & 17 \\
\hline
\end{tabular}

Table 7. Measurements from Permanente and Saratoga Creek December 12,1996 Site locations.-- See Figure 1. and Description of study Area

\begin{tabular}{|c|c|c|c|c|c|c|c|c|c|}
\hline MEASUREMENT & PR1 & PR2 & PR3 & SA1 & SA2 & SA3 & SA4 & SA5 & SA 6 \\
\hline $\mathrm{pH}$ & 8.05 & 8.01 & 7.47 & 8.16 & 7.88 & 8.12 & 8.09 & 7.99 & 7.96 \\
\hline TEMP (C) & 13.4 & 14.3 & 14.0 & 13.7 & 12.7 & 11.7 & 11.5 & 11.4 & 12.4 \\
\hline COND (us $/ \mathrm{cm}$ ) & 770 & 790 & 800 & 340 & 340 & 310 & 290 & 270 & 310 \\
\hline $\mathrm{TSS}$ (mg/L) & 340 & 300 & 0.0 & 40 & 34 & 30 & 14 & 27 & 9.0 \\
\hline ALK (meq/L) & 3.68 & 3.58 & 7.89 & 3.00 & 2.50 & 2.26 & 2.18 & 1.93 & 2.92 \\
\hline $\mathrm{Cl}$ (mg/L) & 35 & 34 & 35 & 12 & 11 & 8.5 & 7.3 & 8.3 & 9.3 \\
\hline $\mathrm{SO} 4(\mathrm{mg} / \mathrm{L})$ & 240 & 250 & 95 & 34 & 33 & 32 & 27 & 27 & 36 \\
\hline $\mathrm{Ca}$ (mg/L) & 100 & 100 & 86 & 38 & 36 & 35 & 31 & 31 & 48 \\
\hline $\operatorname{Mg}(\mathrm{mg} / \mathrm{L})$ & 36 & 36 & 52 & 12 & 9.9 & 8.2 & 9.7 & 5.7 & 8.6 \\
\hline $\mathrm{Na}$ (mg/L) & 25 & 24 & 31 & 14 & 14 & 11 & 11 & 10 & 13 \\
\hline
\end{tabular}


Table 8. Measurements from Permanente and Saratoga Creek January 2, 1997

Site locations.-- See Figure 1. and Description of Study Area

\begin{tabular}{|c|c|c|c|c|c|c|c|c|c|}
\hline MEASUREMENT & PR1 & PR2 & PR3 & SA1 & SA2 & SA3 & SA4 & SA5 & SA 6 \\
\hline $\mathrm{pH}$ & 7.99 & 8.04 & 7.85 & 8.04 & 7.78 & 7.49 & 7.87 & 7.45 & 6.94 \\
\hline TEMP (C) & 12.2 & 16.7 & 13.2 & 12.0 & 12.1 & 11.1 & 10.5 & 13.7 & 10.7 \\
\hline COND (uS/cm) & 590 & 660 & 500 & 270 & 270 & 260 & 220 & 180 & 250 \\
\hline $\mathrm{TSS}$ (mg/L) & 500 & 750 & 76 & 510 & 320 & 250 & 160 & 130 & 45 \\
\hline ALK (meq/L) & 4.58 & $\ldots$ & 4.85 & 1.91 & 1.88 & 1.73 & 1.47 & 1.45 & 1.88 \\
\hline $\mathrm{Cl}$ (mg/L) & 18 & 16 & 17 & 7.6 & 6.8 & 5.8 & 5.4 & 5.7 & 6.5 \\
\hline $\mathrm{SO} 4(\mathrm{mg} / \mathrm{L})$ & 120 & 160 & 19 & 20 & 19 & 21 & 15 & 20 & 19 \\
\hline $\mathrm{Ca}$ (mg/L) & 77 & 90 & 42 & 25 & 26 & 24 & 19 & 22 & 28 \\
\hline $\operatorname{Mg}(\mathrm{mg} / \mathrm{L})$ & 31 & 31 & 30 & 7.6 & 7.3 & 6.2 & 5.2 & 4.3 & 5.1 \\
\hline $\mathrm{Na} \quad(\mathrm{mg} / \mathrm{L})$ & 17 & 15 & 15 & 9.2 & 8.8 & 7.8 & 7.1 & 7.2 & 8.0 \\
\hline
\end{tabular}

Table 9. Measurements from Permanente and Saratoga Creek January 13, 1997 Site locations.-- See Figure 1. and Description of Study Area

\begin{tabular}{|c|c|c|c|c|c|c|c|c|c|}
\hline MEASUREMENT & PR1 & PR2 & PR3 & SA1 & SA2 & SA3 & SA4 & SA5 & SA 6 \\
\hline $\mathrm{pH}$ & 8.1 & 8.15 & 7.87 & 8.13 & 7.92 & 8.10 & 7.99 & 7.99 & 7.94 \\
\hline TEMP (C) & 10.0 & 8.0 & 10.7 & 5.7 & 7.1 & 5.9 & 9.5 & 5.4 & 7.2 \\
\hline COND (uS/cm) & 860 & 880 & 700 & 460 & 460 & 430 & 370 & 430 & 420 \\
\hline TSS (mg/L) & 17 & 36 & 2.3 & 6.7 & 9.0 & 0.0 & 2.0 & 2.0 & 0.0 \\
\hline ALK (meq/L) & 5.44 & 4.85 & 6.56 & 3.19 & 3.12 & 2.89 & 2.51 & 2.68 & 2.94 \\
\hline $\mathrm{Cl}(\mathrm{mg} / \mathrm{L})$ & 26 & 26 & 24 & 14 & 12 & 9.8 & 8.5 & 11 & 9.3 \\
\hline $\mathrm{SO} 4$ (mg/L) & 160 & 190 & 28 & 41 & 40 & 41 & 30 & 45 & 36 \\
\hline $\mathrm{Ca}$ (mg/L) & 94 & 100 & 58 & 48 & 48 & 44 & 36 & 46 & 46 \\
\hline $\operatorname{Mg}(\mathrm{mg} / \mathrm{L})$ & 36 & 34 & 42 & 13 & 12 & 10 & 9.2 & 8.5 & 8.1 \\
\hline $\mathrm{Na}$ (mg/L) & 22 & 23 & 19 & 14 & 14 & 12 & 10 & 12 & 12 \\
\hline
\end{tabular}


Table 10. Measurements from Permanente and Saratoga Creek January 27, 1997

Site locations.-- See Figure 1. and Description of Study Area

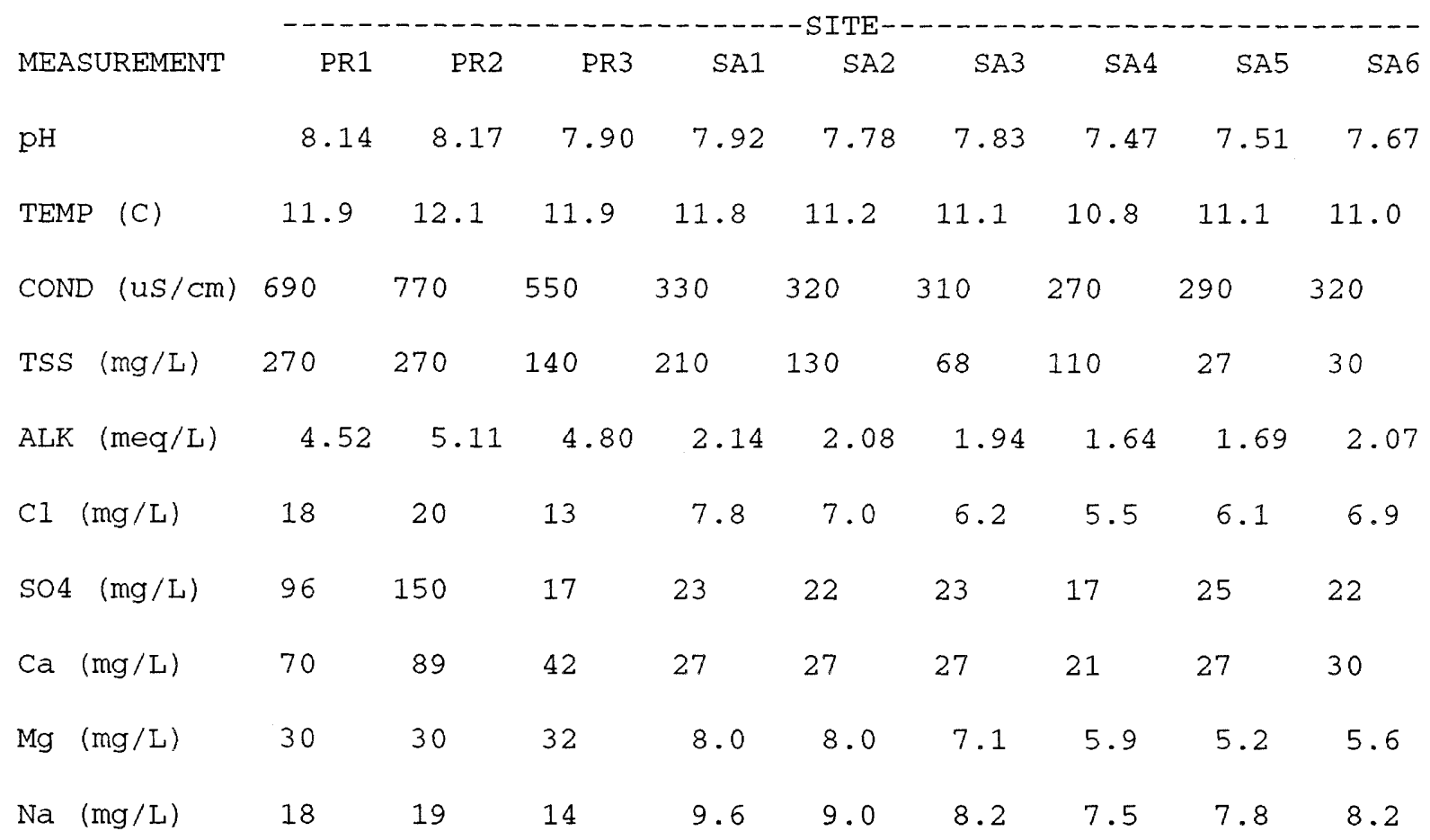

Table 11. Measurements from Permanente and Saratoga Creek February 5, 1997

Site locations.-- See Figure 1. and Description of study Area

\begin{tabular}{|c|c|c|c|c|c|c|c|c|c|}
\hline & ----- & ------ & ------- & ----- & $--S I T E-$ & ------- & ------ & ------- & ---- \\
\hline MEASUREMENT & PR1 & PR2 & PR3 & SA1 & SA2 & SA3 & SA4 & SA5 & SAG \\
\hline $\mathrm{pH}$ & 8.18 & 8.17 & 8.09 & 8.16 & 8.07 & 8.16 & 8.17 & 8.06 & 8.06 \\
\hline TEMP (C) & 10.4 & 10.3 & 10.7 & 9.9 & 9.7 & 8.7 & 8.6 & 8.7 & 9.7 \\
\hline COND (us/cm) & 710 & 740 & 610 & 440 & 410 & 390 & 340 & 390 & 380 \\
\hline $\mathrm{TSS}$ (mg/L) & 34 & 63 & 16 & 38 & 130 & 260 & 9.31 & 1100 & 6.0 \\
\hline ALK (meq/L) & 5.60 & 5.01 & 6.10 & 3.19 & 3.07 & 2.82 & 2.43 & 2.41 & 2.82 \\
\hline $\mathrm{Cl}(\mathrm{mg} / \mathrm{L})$ & 17 & 16 & 16 & 13 & 11 & 9.3 & 8.1 & 10 & 9.0 \\
\hline $\mathrm{SO} 4(\mathrm{mg} / \mathrm{L})$ & 100 & 150 & 22 & 38 & 38 & 38 & 28 & 45 & 35 \\
\hline $\mathrm{Ca}(\mathrm{mg} / \mathrm{L})$ & 85 & 100 & 51 & 49 & 47 & 46 & 38 & --- & 49 \\
\hline $\operatorname{Mg} \quad(\mathrm{mg} / \mathrm{L})$ & 35 & 32 & 38 & 13 & 12 & 10 & 9.0 & --- & 7.8 \\
\hline $\mathrm{Na}(\mathrm{mg} / \mathrm{L})$ & 18 & 16 & 17 & 14 & 14 & 12 & 11 & - - & 13 \\
\hline
\end{tabular}


Table 12. Measurements from Permanente and Saratoga Creek

March 3, 1997

Site locations.-- See Figure 1. and Description of Study Area

\begin{tabular}{|c|c|c|c|c|c|c|c|c|c|}
\hline MEASUREMENT & PR1 & PR2 & PR3 & SAI & SA2 & SA3 & SA4 & SA5 & SA 6 \\
\hline $\mathrm{pH}$ & 8.03 & 8.09 & 7.95 & 8.64 & 8.36 & 8.17 & 8.12 & 7.88 & 7.80 \\
\hline TEMP (C) & 9.6 & 9.2 & 10.3 & 9.7 & 7.4 & 6.9 & 6.9 & 7.0 & 8.1 \\
\hline COND (us/cm) & 880 & 930 & 670 & 500 & 480 & 450 & 390 & 470 & 440 \\
\hline $\operatorname{TSS}(\mathrm{mg} / \mathrm{L})$ & 2.0 & 3.7 & 2.3 & 2.7 & 2.3 & 2.7 & 0.0 & 2.7 & 2.7 \\
\hline ALK (meq/L) & 4.44 & 3.86 & --- & --- & 3.17 & 2.91 & 2.47 & 2.84 & 2.82 \\
\hline $\mathrm{Cl} \quad(\mathrm{mg} / \mathrm{L})$ & 21 & 19 & 21 & 18 & 14 & 11 & 9.2 & 13 & 11 \\
\hline $\mathrm{SO} 4 \quad(\mathrm{mg} / \mathrm{L})$ & 220 & 280 & 30 & 48 & 47 & 47 & 34 & 56 & 43 \\
\hline $\mathrm{Ca}(\mathrm{mg} / \mathrm{L})$ & 103 & 133 & 61 & 46 & 55 & 53 & 43 & 60 & 56 \\
\hline $\operatorname{Mg}(\mathrm{mg} / \mathrm{L})$ & 38 & 35 & 42 & 17 & 15 & 13 & 11 & 10 & 9.8 \\
\hline $\mathrm{Na}$ (mg/L) & 20 & 19 & 19 & 18 & 16 & 14 & 12 & 15 & 13 \\
\hline
\end{tabular}

Table 13. Measurements from Permanente and Saratoga Creek April 1, 1997 Site locations.-- See Figure 1. and Description of Study Area

\begin{tabular}{|c|c|c|c|c|c|c|c|c|c|}
\hline MEASUREMENT & PR1 & PR2 & PR3 & SA1 & SA2 & SA3 & SA4 & SA5 & SA6 \\
\hline $\mathrm{pH}$ & 8.05 & 8.01 & 7.52 & 8.56 & 7.97 & 7.99 & 7.98 & 8.12 & 7.86 \\
\hline TEMP (C) & 11.3 & 10.8 & 12.0 & 15.2 & 10.4 & 8.5 & 8.8 & 8.3 & 8.7 \\
\hline COND (us $/ \mathrm{cm})$ & 660 & 890 & 640 & 530 & 540 & 490 & 410 & 510 & 460 \\
\hline $\operatorname{TSS}(\mathrm{mg} / \mathrm{L})$ & 2.3 & 3.3 & 1.7 & 2.3 & 2.3 & 2.7 & 0.0 & 3.3 & 2.7 \\
\hline ALK (meq/L) & 5.06 & 4.39 & 6.04 & 2.61 & 3.61 & 3.12 & 2.61 & 3.09 & 2.98 \\
\hline $\mathrm{Cl}(\mathrm{mg} / \mathrm{L})$ & 28 & 26 & 24 & 42 & 19 & 12 & 9.2 & 15 & 11 \\
\hline so4 (mg/L) & 150 & 200 & 35 & 42 & 49 & 48 & 36 & 58 & 44 \\
\hline $\mathrm{Ca}(\mathrm{mg} / \mathrm{L})$ & 98 & 108 & 64 & 42 & 60 & 58 & 45 & 64 & 58 \\
\hline $\operatorname{Mg}(\mathrm{mg} / \mathrm{L})$ & 41 & 37 & 44 & 15 & 18 & 13 & 12 & 11 & 10 \\
\hline $\mathrm{Na} \quad(\mathrm{mg} / \mathrm{L})$ & 24 & 22 & 21 & 32 & 19 & 15 & 13 & 17 & 14 \\
\hline
\end{tabular}


Table 14. Measurements from Permanente and Saratoga Creek May 2, 1997

Site locations.-- See Figure 1. and Description of study Area

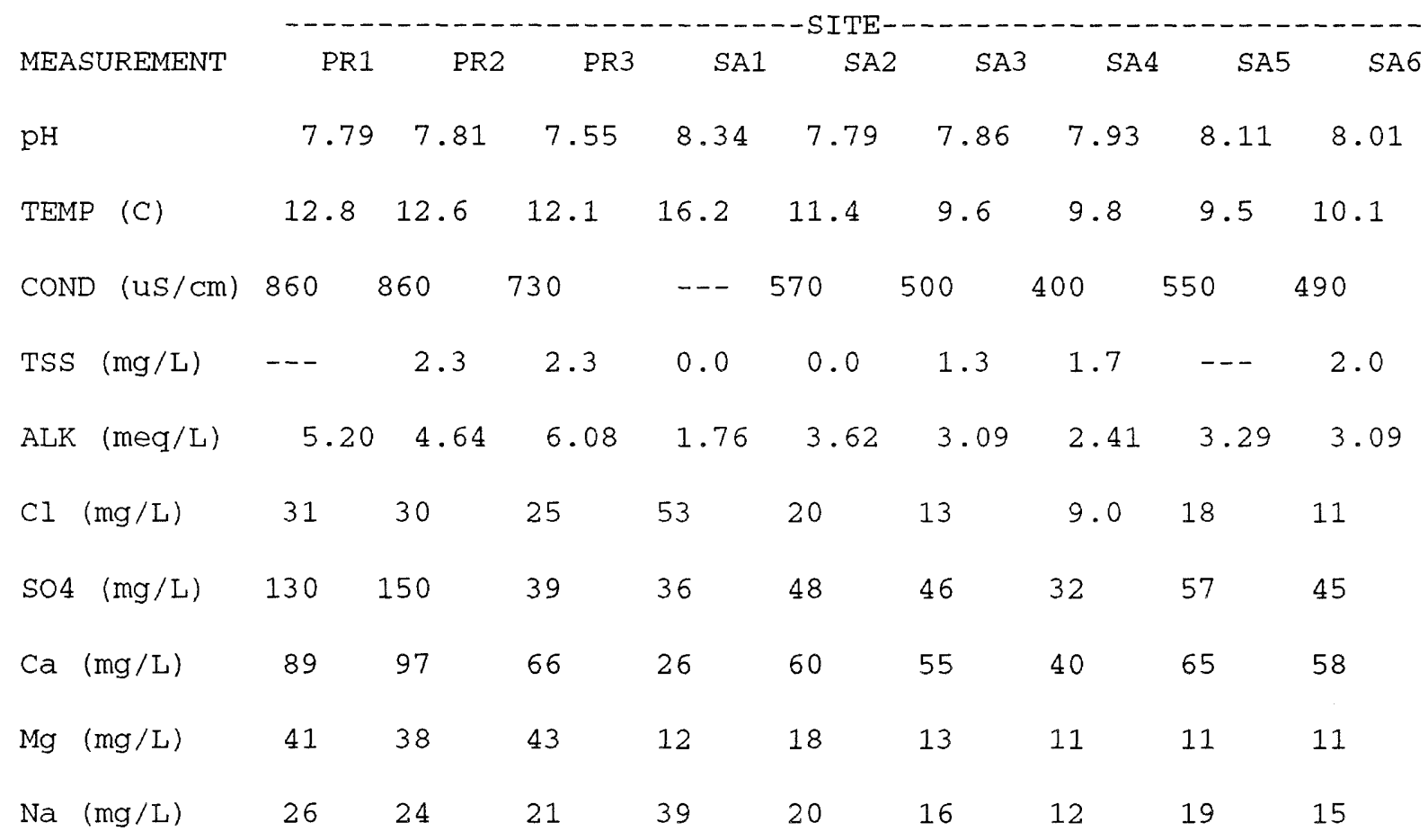

Table 15. Measurements from Permanente and Saratoga Creek June 10, 1997

Site locations.-- See Figure 1. and Description of Study Area

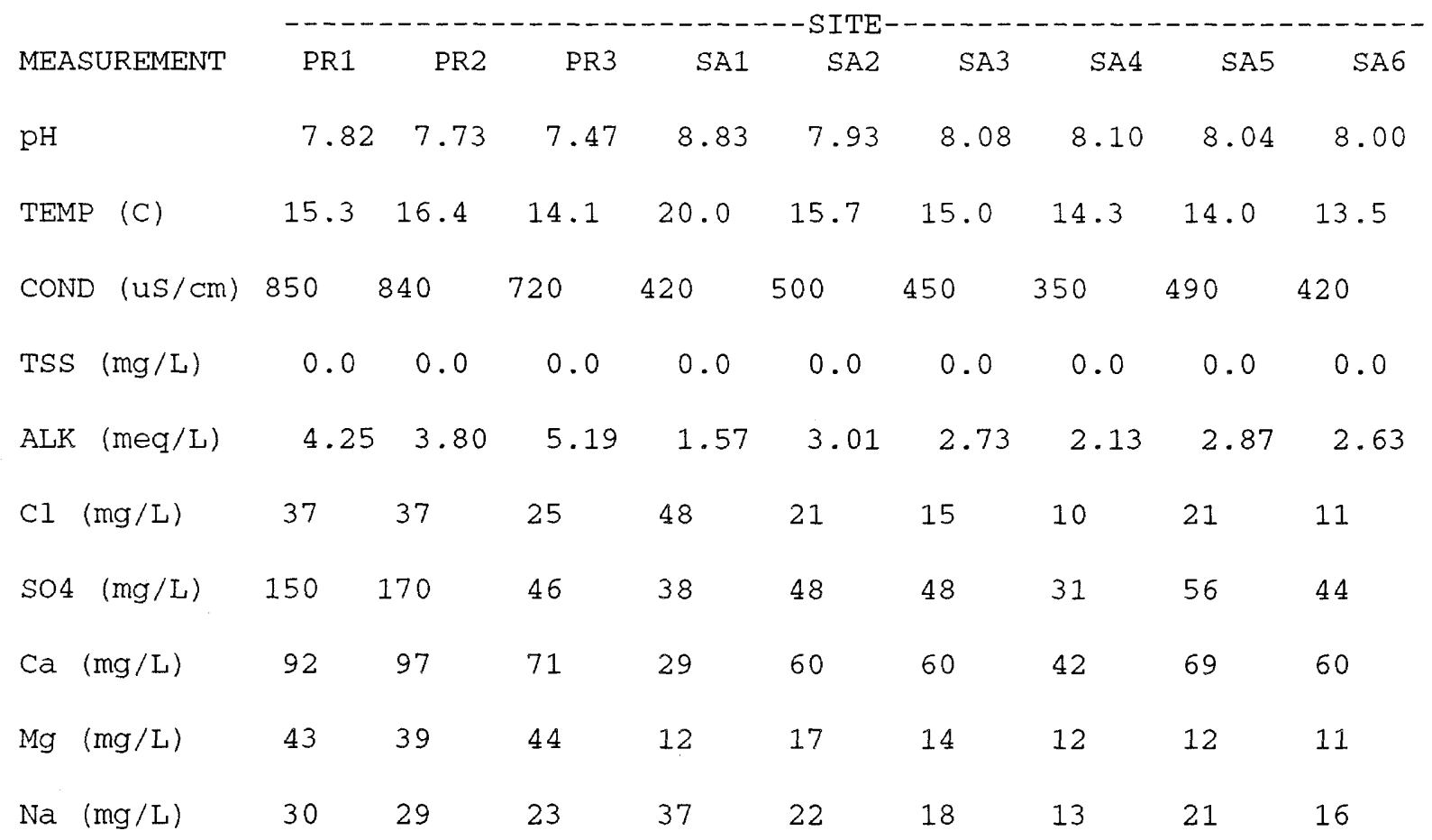


Table 16. Measurements from Permanente and Saratoga Creek July 8, 1997

Site locations.-- See Figure 1. and Description of study Area

\begin{tabular}{|c|c|c|c|c|c|c|c|c|c|}
\hline MEASUREMENT & PR1 & PR2 & PR3 & SA1 & SA2 & SA3 & SA4 & SA5 & SA6 \\
\hline $\mathrm{pH}$ & 7.67 & 7.96 & 7.36 & 8.59 & 7.66 & 8.15 & 8.03 & 8.13 & 7.94 \\
\hline TEMP (C) & 15.6 & 16.4 & 15.0 & 25.9 & 18.6 & 15.4 & 15.3 & 15.5 & 15.9 \\
\hline COND (us/cm) & 850 & 820 & 710 & 300 & 520 & 420 & 300 & 490 & 420 \\
\hline TSS (mg/L) & 0.0 & 0.0 & 0.0 & 0.0 & 0.0 & 0.0 & 0.0 & 0.0 & 0.0 \\
\hline ALK (meg/L) & 4.62 & 4.11 & 5.29 & 0.99 & 3.21 & 2.61 & 1.93 & 2.98 & 2.67 \\
\hline Cl (mg/L) & 39 & 41 & 27 & 40 & 28 & 15 & 9.2 & 24 & 11 \\
\hline $\mathrm{SO} 4$ (mg/L) & 150 & 160 & 49 & 25 & 48 & 45 & 29 & 56 & 44 \\
\hline $\mathrm{Ca}$ (mg/L) & 96 & 110 & 74 & 17 & 62 & 58 & 38 & 72 & 60 \\
\hline $\mathrm{Mg} \quad(\mathrm{mg} / \mathrm{L})$ & 47 & 38 & 45 & 8.8 & 20 & 13 & 10 & 12 & 11 \\
\hline $\mathrm{Na} \quad(\mathrm{mg} / \mathrm{L})$ & 33 & 29 & 26 & 30 & 27 & 18 & 13 & 23 & 17 \\
\hline
\end{tabular}

Table 17. Measurements from Permanente and Saratoga Creek August 15, 1997 Site locations.-- See Figure 1. and Description of Study Area

\begin{tabular}{|c|c|c|c|c|c|c|c|c|c|}
\hline MEASUREMENT & PR1 & PR2 & PR3 & SA1 & $\mathrm{SA} 2$ & $\mathrm{SA} 3$ & SA4 & SA 5 & SA 6 \\
\hline $\mathrm{pH}$ & 8.01 & --- & 7.49 & 8.42 & 7.75 & 8.26 & 7.97 & 8.23 & 7.95 \\
\hline TEMP (C) & 16.3 & --- & 15.7 & 23.9 & 21.5 & 16.5 & 16.1 & 16.4 & 16.7 \\
\hline COND (US/ cm) & 900 & --- & 740 & 300 & 550 & 460 & 330 & 530 & 430 \\
\hline $\operatorname{TSS}$ (mg/L) & 0.0 & --- & 0.0 & 0.0 & 0.0 & 0.0 & 0.0 & 0.0 & 0.0 \\
\hline ALK (meq/L) & 4.69 & --- & 5.36 & 0.96 & 3.29 & 2.74 & 2.04 & 3.06 & 2.76 \\
\hline $\mathrm{Cl}(\mathrm{mg} / \mathrm{L})$ & 43 & --- & 28 & 34 & 31 & 18 & 9.8 & 28 & 12 \\
\hline SO4 (mg/L) & 150 & --- & 52 & 23 & 47 & 45 & 29 & 56 & 42 \\
\hline $\mathrm{Ca}(\mathrm{mg} / \mathrm{L})$ & 81 & --- & 61 & 15 & 54 & 51 & 33 & 61 & 51 \\
\hline $\mathrm{Mg} \quad(\mathrm{mg} / \mathrm{L})$ & 50 & --- & 45 & 9.7 & 20 & 14 & 11 & 13 & 11 \\
\hline $\mathrm{Na} \quad(\mathrm{mg} / \mathrm{L})$ & 34 & --- & 26 & 27 & 28 & 20 & 14 & 26 & 18 \\
\hline
\end{tabular}


Table 18. Measurements from Permanente and Saratoga Creek September 19, 1997

Site locations.-- See Figure 1. and Description of Study Area

\begin{tabular}{|c|c|c|c|c|c|c|c|c|c|}
\hline MEASUREMENT & PR1 & PR2 & PR3 & SAI & $\mathrm{SA} 2$ & SA3 & SA4 & SA5 & SA6 \\
\hline $\mathrm{pH}$ & 7.92 & --- & 7.29 & 8.55 & 7.50 & 8.01 & 7.82 & 8.04 & 7.78 \\
\hline TEMP (C) & 16.0 & --- & 15.4 & 21.6 & 18.3 & 15.1 & 14.7 & 14.5 & 14.6 \\
\hline COND (us/cm) & 910 & $-\cdots$ & 760 & 300 & 560 & 450 & 330 & 530 & 420 \\
\hline $\operatorname{TSS}(\mathrm{meq} / \mathrm{L})$ & 0.0 & -- & 0.0 & 0.0 & 0.0 & 0.0 & 0.0 & 0.0 & 0.0 \\
\hline ALK $\quad(\mathrm{mg} / \mathrm{L})$ & 4.75 & -- & 5.56 & 1.73 & 3.37 & -- & 2.05 & 3.12 & 2.80 \\
\hline $\mathrm{Cl}(\mathrm{mg} / \mathrm{L})$ & 47 & --- & 29 & 19 & 34 & 20 & 10 & 31 & 13 \\
\hline $\mathrm{SO} 4(\mathrm{mg} / \mathrm{L})$ & 160 & -- & 54 & 27 & 47 & 45 & 29 & 55 & 42 \\
\hline $\mathrm{Ca}(\mathrm{mg} / \mathrm{L})$ & 83 & -- & 65 & 20 & 54 & 53 & 34 & 64 & 51 \\
\hline $\operatorname{Mg}(\mathrm{mg} / \mathrm{L})$ & 51 & -- & 48 & 14 & 21 & 14 & 11 & 13 & 12 \\
\hline $\mathrm{Na} \quad(\mathrm{mg} / \mathrm{L})$ & 35 & --- & 26 & 21 & 28 & 20 & 14 & 39 & 18 \\
\hline $\begin{array}{rrr}\text { * AT PR2 } & \text { PER } \\
\text { NO SAMPLE } & \text { TAK }\end{array}$ & $\begin{array}{l}\text { MANENTE } \\
\text { EN }\end{array}$ & EEK & $S F L$ & $\mathrm{NG} \quad 0 \mathrm{I}$ & $\Delta \mathrm{YH}$ & $\mathrm{H} \quad \mathrm{TH}$ & TREA & ED, & \\
\hline
\end{tabular}

